\title{
Adipose-Derived Stromal/Stem Cells from Large Animal Models: from Basic to Applied Science
}

\author{
Joanna Bukowska ${ }^{1}$ (D) Anna Zuzanna Szóstek-Mioduchowska ${ }^{1} \cdot$ Marta Kopcewicz $^{1} \cdot$ Katarzyna Walendzik $^{1}$. \\ Sylwia Machcińska ${ }^{1}$ Barbara Gawrońska-Kozak ${ }^{1}$
}

Accepted: 25 September 2020 / Published online: 6 October 2020

(C) The Author(s) 2020

\begin{abstract}
Adipose-derived stem cells (ASCs) isolated from domestic animals fulfill the qualitative criteria of mesenchymal stem cells, including the capacity to differentiate along multiple lineage pathways and to self-renew, as well as immunomodulatory capacities. Recent findings on human diseases derived from studying large animal models, have provided evidence that administration of autologous or allogenic ASCs can improve the process of healing. In a narrow group of large animals used in bioresearch studies, pigs and horses have been shown to be the best suited models for study of the wound healing process, cardiovascular and musculoskeletal disorders. To this end, current literature demonstrates that ASC-based therapies bring considerable benefits to animal health in both spontaneously occurring and experimentally induced clinical cases. The purpose of this review is to provide an overview of the diversity, isolation, and characterization of ASCs from livestock. Particular attention has been paid to the functional characteristics of the cells that facilitate their therapeutic application in large animal models of human disease. In this regard, we describe outcomes of ASCs utilization in translational research with pig and horse models of disease. Furthermore, we evaluate the current status of ASC-based therapy in veterinary practice, particularly in the rapidly developing field of equine regenerative medicine. In conclusion, this review presents arguments that support the relevance of animal ASCs in the field of regenerative medicine and it provides insights into the future perspectives of ASC utilization in animal husbandry.
\end{abstract}

Keywords Adipose-derived stem cells $\cdot$ Livestock animals $\cdot$ Animal models $\cdot$ Therapeutic application

\section{Introduction}

Mesenchymal stem cells (MSCs) can be isolated from a large variety of tissue sources, among which bone marrow

Joanna Bukowska

j.bukowska@pan.olsztyn.pl

Anna Zuzanna Szóstek-Mioduchowska

a.szostek-mioduchowska@pan.olsztyn.pl

Marta Kopcewicz

m.kopcewicz@pan.olsztyn.pl

Katarzyna Walendzik

k.walendzik@pan.olsztyn.pl

Sylwia Machcińska

s.machcinska@pan.olsztyn.pl

Barbara Gawrońska-Kozak

b.kozak@pan.olsztyn.pl

1 Institute of Animal Reproduction and Food Research, Polish Academy of Sciences, Tuwima 10, 10-748 Olsztyn, Poland mesenchymal stem cells (BMSCs), first identified in 1968 by Friedenstein et al. [1], have been the most extensively investigated. However, due to the limitations related to BMSC procurement, mostly reflected by the high risk of morbidity associated with the bone marrow aspiration procedure and the critically low yield of isolated MSCs $(0.001 \%-0.01 \%$ of the harvested bone marrow cells), there has been a growing need to explore an alternative source of MSCs [2]. Discovery/ appreciation of adipose tissue as an abundant source of MSCs led to overcoming the BMSC-associated obstacles and introduced a new type of MSCs named adipose-derived stem cells (ASCs) [3]. Indeed, fat tissue deposits are accessible, and they can be obtained from multiple sites in large quantities. In this context, one of the main advantages of ASCs over BMSCs is that adipose tissue can be easily harvested using minimally invasive procedures, such as liposuction and chirurgic interventions, that in humans are employed as methods for excess fat removal, and in the case of farm animals, adipose tissue can be obtained from slaughterhouses [4, 5]. Another biological feature that advocates for ASCs is their lifespan during in vitro culture. As demonstrated by Kern et al., BMSCs 
exhibited signs of cell senescence at passage 7, whereas ASCs can be cultivated up to passage 8 without any sign of decline [6]. Although significant differences have been reported between human ASCs and BMSCs, both populations demonstrate comparable characteristics in terms of morphology, surface markers, and differentiation potential [7-9]. Moreover, numerous similarities between these cells were confirmed based on transcriptomic analysis [10].

ASCs have received considerable attention over the past decades, mainly because of their therapeutic potential in different areas of applied science [11-13]. Although the initial method of cell isolation from adipose tissue was established using laboratory rodents [14-17], soon thereafter ASCs were isolated from human fat [3]. Human ASCs (hASCs) have now been extensively studied and are employed in preclinical and clinical studies $[18,19]$. In recent years ASCs from domestic animals have gained increased attention, primarily because of the accumulating evidence demonstrating their remarkable plasticity, differentiation potential, expression of pluripotency markers, and immunomodulatory properties at levels comparable to those observed in hASCs [20,21]. Together, these modalities strongly endorse farm animal ASCs as potential therapeutic agents that can be widely considered for clinical application in veterinary medicine. At present, many veterinary clinics take advantage of autologous or allogenic ASCs to treat various diseases in animals. In particular, cell-based therapies using ASCs are increasingly being reported in equine medicine because this field involves a large number of animals prone to frequent injuries to tendons, joints, cartilage, and bones (reviewed in [22]). Last but not least, an important reason to support the use of large animal models as a target for ASC administration is that they provide insights into disease mechanisms and models for determining the efficacy and safety of cell-based therapies. Among these, the animal model that shows results parallel to those expected in humans is pigs [23].

This review combines basic and applied science to discuss ASCs in the context of veterinary medicine. We describe the recent advances in studies of the source, isolation, and characterization of ASCs from livestock. Particular attention is directed toward the functional characteristics of cells that facilitate their application in large animal models for improving repair of multiple tissues in both humans and animals. In this review, we also provide an overview of the translational studies that demonstrate application of ASCs in some important pig models. Moreover, we evaluated the current status of ASC-based therapy in animals, particularly in rapidly developing equine regenerative medicine.
Basic Biology of ASCs Isolated from Livestock

\section{Fat-Depot-Dependent Quantity of ASCs}

The most abundant type of adipose tissue in adult mammals is white adipose tissue (WAT), which serves multiple functions, including energy storage and endocrine activity [24]. WAT is composed of a heterogeneous population of cells with the two main cell fractions being lipid-filled adipocytes and the stromal vascular fraction (SVF) that contains the population of ASCs [25]. Routinely, during cell isolation and culture procedures, ASCs are purified from SVF by adherence to plastic and further expansion in culture [25]. In mammals, WAT depots occupy different anatomical locations and demonstrate morphological and functional heterogeneity [26]. In the pig, abdominal and dorsal regions of subcutaneous fat have been the most frequently used source of ASCs [27-30]. There is only one report that refers to the caudal part of the body for ASC isolation [31]. Similarly, very few investigations have described pig ASCs (pASCs) collected from visceral or inguinal fat $[32,33]$. In equine studies, similar to porcine studies, the large body of data has been obtained based on subcutaneous fat [20, 34-36]. However, the sites chosen for subcutaneous adipose tissue harvesting seem to be far more diverse than in other animal species and include the paracoccygeal region, supragluteal area, the region above the dorsal gluteal muscles, the tail base (tail head), and the area lateral to the insertion of the tail [20, 37-40]. However, other tissues, including intraperitoneal adipose tissue, omentum, hepatic falciform ligament and mesenteric lipomas, have also been reported as a source of ASCs [37, 41]. Interestingly, in other domestic animals, such as sheep and cows, data reveal the presence of ASCs in unique locations, such as the infrapatellar fat pad and the hoof interdigital region, respectively $[42,43]$.

In the current literature, there are limited comparative studies referring to cell yield or isolation method efficiency between different fat depots or different mammalian species [Table 1]. One example of comparative studies is that by Perruchot et al. [28]. Considering the developmental and functional link between adipose tissue and skeletal muscle [45], the authors compared pASCs isolated from subcutaneous dorsal adipose tissue (SCAT) and intermuscular (interM) fat, to cells collected from skeletal muscle. They showed a lower number of SVF cells isolated from interM fat depot compared to other examined tissues regardless of donor age (7-, 160-, 400-days old). Moreover, immunophenotypic analysis of SVF cells revealed that, whereas the proportion of CD90+ cells increased in interM fat and muscles in adult pigs, the pattern did not change with age in SCAT. However, another report by Niada et al. [44] demonstrated no differences in viability, proliferation, clonogenicity and adipogenic, osteogenic, or chondrogenic differentiation between pASCs from subcutaneous interscapular fat and buccal fat pads. Interestingly, this 
Table 1 Yield of $\mathrm{ASCs}^{\mathrm{a}}$ isolated from different fat depots in pigs and horses

\begin{tabular}{|c|c|c|c|c|c|}
\hline Animal & Sex and Age & Fat depot & Number of cells & $\begin{array}{l}\text { Unit(number } \\
\text { of cells per) }\end{array}$ & References \\
\hline Pig & $\begin{array}{l}\text { Females and } \\
\text { males, } \geq 4-5- \\
\text { month-old }\end{array}$ & $\begin{array}{l}\text { Subcutaneous interscapular } \\
\text { fat (ScI-pASCs); Buccal fat } \\
\text { pads (BFP-pASCs) }\end{array}$ & $5.5 \times 10^{4}\left( \pm 3.3 \times 10^{4}\right) ; 3.0 \times 10^{4}\left( \pm 9.3 \times 10^{3}\right)$ & $\begin{array}{c}\mathrm{mL} \text { raw } \\
\text { tissue }\end{array}$ & {$[44]$} \\
\hline Pig & $\begin{array}{r}\text { Females, } 7,160, \\
400 \text { days old }\end{array}$ & $\begin{array}{l}\text { Subcutaneousdorsal adipose } \\
\text { tissue } \\
\text { (SCAT); Intermuscular } \\
\text { (interM) adipose tissue }\end{array}$ & $\begin{array}{l}2.0 \times 10^{7}\left( \pm 0.5 \times 10^{6} ; 7 \text { days old }\right) ; 6.0 \times 10^{6}( \pm \\
\left.0.2 \times 10^{6} ; 160 \text { days old }\right) ; 2.6 \times 10^{6}\left( \pm 0.2 \times 10^{6} ;\right. \\
\quad 400 \text { days old }) ; 5.5 \times 10^{6}\left( \pm 0.4 \times 10^{6} ; 7 \text { days }\right. \\
\text { old }) ; 0.3 \times 10^{6} \\
\left( \pm 0.03 \times 10^{6} ; 160 \text { days old }\right) ; 1.8 \times 10^{6}\left( \pm 0.3 \times 10^{6} ;\right. \\
400 \text { days old })\end{array}$ & gram tissue & {$[28]$} \\
\hline Pig & Not referenced & Caudal region & $1.8 \times 10^{5}\left( \pm 4.7 \times 10^{4}\right)$ & $\begin{array}{l}\mathrm{mL} \text { raw } \\
\text { tissue }\end{array}$ & {$[31]$} \\
\hline Horse & Median age 4.5 years & Supragluteal region & $1.78 \times 10^{6}$ & gram tissue & {$[38]$} \\
\hline
\end{tabular}

${ }^{\mathrm{a}}$ ASCs, adipose derived stromal/stem cells

data supported future clinical applications of stem cells from buccal fat, the depot that is discarded tissue during cosmetic surgery for cheek reduction in humans [46]. Moreover, Burk et al. [38] found that adipose tissue provided a higher number of cells per tissue unit as compared to umbilical cord blood or flexor tendon. In addition, the culture time for primary cells (passage 0 ) was shorter for ASC (6 days) than for bone marrow MSCs (14 days).

\section{ASC Isolation and In Vitro Propagation}

Rodbell and colleagues in the 1960s [14-17] pioneered the procedures for isolation of ASCs from adipose tissue by a series of experiments on rat epididymal fat. Despite a number of minor modifications made to the initial protocol through the years, the core method remains unchanged and relies on collagenase digestion at $37^{\circ} \mathrm{C}$ with continuous agitation $[47,48]$. Samples are then centrifuged in order to separate the floating population of mature adipocytes from the pelleted SVF. Finally, the resulting heterogenous SVF can be seeded into culture dishes in medium containing fetal bovine serum (FBS) to further expand the plastic-adherent population of ASCs [47] (Fig. 1). Consistently, numerous animal studies show that the collagenase concentration (primarily type I or II) varies between $0.01 \%$ and $0.2 \%$ with very strong representation of protocols demonstrating $0.1 \%$ as an appropriate dilution of the enzyme $[21,29,49]$. There are also reports describing a combined enzyme procedure composed of trypsin $(w / v, 0.25 \%)$ and collagenase type I $(\mathrm{w} / \mathrm{v}, 0.1 \%$ or $0.2 \%)$ that was used for ASC isolation from abdominal fat of cattle [50] and from ovine adipose tissue [51]. Medical products, including Matrase ${ }^{\mathrm{TM}}$, have also been reported to have been used [52].

ASC proliferation has been demonstrated to be speciesspecific and highly dependent on the culture medium used. Indeed, Schwartz et al. [29] found that population doubling time (PDT) of pig ASCs varied between $65 \pm 7 \mathrm{~h}$ for cells cultured in medium supplemented with FBS and $54 \pm 3 \mathrm{~h}$ in medium supplemented with serum substitute. Other studies showed that the PDT of pig ASCs was $54 \pm 19 \mathrm{~h}$ in serumcontaining medium [31]. A similar discrepancy has been observed in studies that used bovine ASCs [43, 53]. Independent studies from two laboratories have demonstrated that the PDT of cells from passage 1 to 5 extended and reached values of $16.44 \pm 0.33 \mathrm{~h}$ and $22.06 \pm 0.32 \mathrm{~h}$, respectively, whereas other investigators have reported a constant PDT from passage 1 to 9 that equals $30 \pm 1.9 \mathrm{~h}[43,53]$. Similarly, no differences in the proliferative ratio of ASCs were observed in ovine ASC cultures during progressive expansion up to passage 6 [42]. In horse ASCs, the PDT was shown to be $24.23 \pm 4.45 \mathrm{~h}$ [54]. In contrast, others revealed that under comparable culture conditions the PDT of equine ASCs was $2.2 \pm 0.2$ days [40]. Although the proliferation of equine ASCs has been shown to be highly variable, there is considerable evidence that this function is greater in ASCs than in bone marrow MSCs [38, 40] or umbilical cord MSCs [38]. Moreover, studies by Marycz et al. [55] shed light on ASC functional characteristics in terms of health status of the animals. In this particular study, the authors prepared ASCs isolated from healthy donors and horses affected by equine metabolic syndrome (EMS), manifested by pathological obesity, hyperglycemia, hyperinsulinemia, and insulin resistance [39]. ASCs derived from EMS ( $\mathrm{ASC}_{\mathrm{EMS}}$ ) horses exhibited significantly decreased proliferation at 7 days of culture and required more time to double their population $(73.75 \pm 6.54 \mathrm{~h})$, compared with ASCs from healthy donors, with a PDT of $51.12 \pm 5.32 \mathrm{~h}$ [55]. In addition, ASCs $\mathrm{S}_{\mathrm{EMS}}$ exhibited a senescent phenotype manifested by $\beta$-galactosidase accumulation and displayed numerous degeneration-related indicators, such as increased amounts of nitric oxide (NO) and reactive oxygen species (ROS), reduced superoxide dismutase (SOD) activity, and a growing number of impaired mitochondria. Interestingly, in a further study, the same group demonstrated characteristics of equine ASCs as a function of age [34]. ASCs derived from 
Fig. 1 Schematic illustration depicting fat tissue processing, isolation of stromal vascular fraction cells (SVFs), and culture expansion of adipose-derived stromal/stem cells (ASCs). Verification of the functionality of SVFs/ASCs in vitro and the identification of their surface markers should be an obligatory step to approve cells as an off-theshelf product

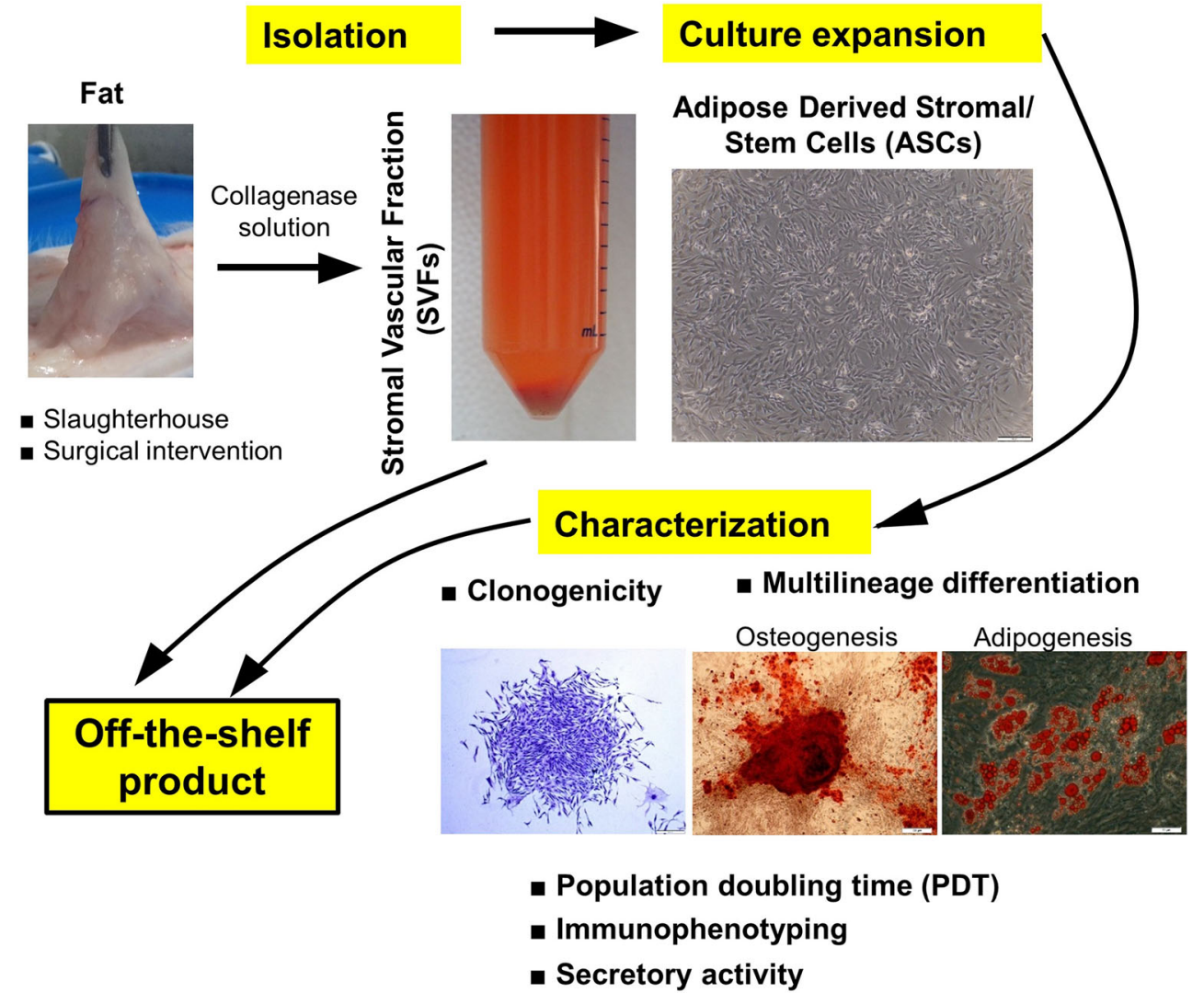

and advantages of cryopreserved pASCs that can be considered for cell banking and future use in preclinical studies and therapeutic applications.

\section{Stemness-Related Markers}

In 2013 the International Federation for Adipose Therapeutics and Science (IFATS) and the International Society for Cellular Therapy (ISCT), represented by Bourin and coworkers [25], provided guidance regarding the minimal criteria expected for ASCs. These properties have been broadly used as the gold standard in characterization of ASCs derived from both humans and animals.

Animal ASCs are commonly described based on their clonogenicity, immunophenotype, and trilineage differentiation potential into adipogenic, ostegenic, and chondrogenic lineages. Clonogenicity, described also as a colony-formingunit fibroblast (CFU-F) [57], has been observed in a majority of ASC cultures regardless of donor species. Certainly, the potential to create colonies from a single cell depends on passage number. Having compared clonogenicity of pig ASCs at P0, P5, P10, P15, and P20, Tang et al. [58] showed a decline in the number of CFU-Fs in higher passages and demonstrated that the number of colonies at each passage was $1041 \pm 19.3$, $713 \pm 22.1,280 \pm 16.7,36 \pm 2.9$, and 0 , respectively. In addition, in horse studies, the reduction in number of colonies was 
observed in ASCs from a lipoma and in cultures established from an EMS fat depot [37, 39]. It is noteworthy that da Silva Meirelles et al. [59] found a correlation between CFU-F number and blood vessel density. In this study, ASCs were isolated from horse subcutaneous fat of the tail head showed increased vascularity relative to the adipose tissue in the area lateral to the tail insertion. The CFU-F numbers per mg of adipose tissue were next examined as a function of the area occupied by blood vessels in each sample. The results revealed a strong correlation $\left(r^{2}=0.86\right)$ between these two modalities, supporting the earlier findings suggesting that the perivascular region can create the niche for adipose tissue stem cells [60]. However, it should be mentioned that the study was performed with a small number of replicates $(n=2)$ and without quantification of specific markers for endothelial cells or pericytes due to the lack of specific anti-horse antibodies and the lack of reactivity of anti-human antibodies [59].

ASCs are routinely characterized using a panel of surface markers or occasionally pluripotency-associated markers, including Oct4, Nanog, and Sox2, which have been shown to be expressed in pig ASCs [21, 30, 61, 62]. Despite any differences in species or fat depot, the immunophenotype of ASCs is uniformly consistent between laboratories [62-65]. Indeed, according to the current literature, markers that show strong positive expression on livestock ASCs are CD29, CD44, CD73, CD90, and CD105, whereas CD11b, CD14, CD34, CD45, and HLA-DR demonstrate low or lacking expression [62-65]. The expression profile of selected markers might change as a function of donor age. A study of pigs at different ages (7-, 160-, 400-days-old) revealed that the percentage of CD90 cells from the intermuscular region is elevated in adult animals (400-days-old) [28]. In horses, no significant differences were observed between ASCs and BMSCs. The percentage of CD29+ cells was $99 \%$ for ASCs and 90\% for BMSCs; $87 \%$ of ASCs and $64 \%$ of BMSCs expressed CD105, whereas $99 \%$ of both demonstrated the presence of CD44 [66].

Being of mesodermal origin, the animal ASCs have demonstrated potential to differentiate into adipogenic, chondrogenic, and osteogenic lineages, regardless of species origin $[20,50,52,62]$. Additionally, there is considerable evidence that, upon stimulation with specific induction media, ASCs are able to acquire the phenotype and function of cells belonging to ectodermal and endodermal lineages [30, 32, 65]. Principally, these abilities have accounted for application of ASCs in regenerative medicine. Comparative studies [20] revealed that adipogenic differentiation, evaluated based on accumulation of lipid droplets, was more noticeable in equine ASCs than in their human counterparts. A separate study demonstrated that the degree of osteogenic differentiation determined by extracellular calcium deposition was comparable in ASCs, BMSCs, and tendon MSCs, and subsequently, the process was more pronounced in these cells than in MSCs derived from umbilical cord blood or umbilical cord tissue from horses [38]. Furthermore, differentiation capacity changed with time in culture Zhao et al. [43] observed reduced adipogenesis and chondrogenesis of bovine ASCs at P5 relative to the cultures at P2. However, propagation during passages favored osteogenic differentiation as ASCs showed increased activity of alkaline phosphatase (ALP) at P5 relatively to P2 [43]. These findings are consistent with data obtained from pig ASCs demonstrating a decrease in adipogenic properties with increasing passage number (from P1 to P12), whereas the cells at late passage (P12) displayed enhanced osteogenesis compared with early (P1) and middle (P6) passages [33].

\section{Functional In Vitro Validation of Animal ASCs as an Introduction to Preclinical Application}

Over the last few years, intensive research efforts have focused on developing cell-therapy products aiming to improve the cure of numerous disorders $[67,68]$. Concomitantly, there has been debate in the stem cell field that questions the level of basic science knowledge necessary to enter clinical trials [69]. Certainly, the cellular strategies should reach the status of research-grade products prior to introducing a translational phase. There is a common opinion that the success of stem cells in regenerative medicine is profoundly dependent on their functional qualities, which should be thoroughly verified in vitro (Fig. 1).

There has been considerable progress in ASC propagation and differentiation protocols, anticipating the use of new treatments including growth factors, biomaterials, hypoxia, or even physical agents (e.g., magnetic fields) [36, 54, 65, 70-72]. These modalities provide improvements in ASC function and increase the chance of achieving beneficial outcomes in damaged tissue.

\section{Trans-Differentiation}

In addition to the aforementioned properties of trilineage differentiation of adipogenic, chondrogenic, and osteogenic lines, animal ASCs were shown to possess the capacity to generate in vitro a vast array of cell types across germ line boundaries. Studies on pigs demonstrated that ASCs can be induced to produce hepatocytes in hepatocyte-differentiation medium [32]. Liu et al. [65] found that ASCs derived from piglet subcutaneous fat showed the ability to transdifferentiate into pancreatic islet-like clusters (PILCs), which was confirmed by expression of tissue-specific proteins, such as pancreatic and duodenal homeobox (Pdx-1), insulin and insulin gene enhancer protein (ISL-1). It is noteworthy that ELISA results showed that PILCs released high amounts of insulin into the culture medium upon glucose challenge. Moreover, a 
study using pig ASCs demonstrated myogenic and cardiomyogenic differentiation of pASCs, following incubation with culture medium supplemented with hydrocortisone or retinoic acid, respectively, together with other reagents [62]. In this case, long-term ASC culture (19 days) resulted in the formation of parallel, tightly packed structures resembling myofibers. Although the study showed lack of functional examination, immunofluorescence staining using human antibodies detected the presence of muscle and cardiac proteins, including $\alpha$-sarcomeric actin, myogenin, myod1, desmin, cardiotin, and GATA-6, in ASC cultures [62]. Given the fact that biomedical research has employed ASCs in the area of myocardial dysfunction [73], such investigations can shed light on possible utilization of ASCs in veterinary practice. Furthermore, Song et al. [30] demonstrated the potential of pASCs for in vitro oogenesis. Indeed, after introduction of differentiation medium, ASCs exhibited formation of oocyte-like precursor cells by day 12 . These observations were evaluated based on morphological changes displaying the formation of thecal, granulosa, or cumulus-like cells, and they were confirmed at the level of marker mRNA expression, including Oct-4, growth differentiation factor $9 b$ (GDF9b), cMos, Vasa, deleted in azoospermia-like (DAZL), zona pellucida $C(Z P C)$, and follicle-stimulating hormone receptor (FSHR) [30].

Significant advances in the field of animal ASCs were provided by establishing pig induced pluripotent stem cells (piPSCs) from ASCs [58, 74]. Tang et al. [58] used retroviral transduction to reprogram pASCs and BMSCs. The reprogramming efficiency was comparable in both type of cells. Although the cells were not completely reprogrammed, they showed embryoid body formation and expressed glial fibrillary acidic protein (GFAP), alpha fetoprotein (AFP), and bone morphogenetic protein 4 (BMP4) mRNA, which are relevant to the ectoderm, endoderm, and mesoderm, respectively. In a separate study, cell reprogramming was accomplished using doxycycline (DOX)-inducible lentiviral vectors encoding Yamanaka factors (Oct4, Sox2, c-Myc, and Klf4) and a unique culture system with no feeder layer and serum supplementation [74]. At a functional level, successful reprogramming of naive-like piPSCs was confirmed by differentiating into cell types of all three germ layers in vitro and in vivo. Because iPSCs can further serve as an alternative to embryonic stem cells (ESCs) facilitating formation of any germ layer, they might be considered "personalized" cell products.

\section{ASC Secretory Activity}

A mechanism by which MSCs improve tissue repair includes both differentiation and paracrine signaling $[75,76]$. However, because cumulative data on laboratory rodents indicated that the levels of improvement achieved with MSC application do not always correspond with the levels of cellular engraftment, it was assumed that the paracrine activity of MSCs is the primary mechanism accounting for their beneficial effects in responses to injury $[75,76]$. This concept was further supported by studies demonstrating that not only MSCs alone but also MSC-conditioned medium has the ability to enhance tissue repair $[77,78]$.

While the trophic effects produced by the secretion of bioactive factors by MSCs have been widely reported in human and mouse (reviewed in $[79,80]$ ), there is a limited number of studies showing the analogous properties of ASCs derived from farm animals. Pascucci et al. [81] demonstrated that equine ASC monolayers constitutively produce membrane vesicles (MVs) that mediate angiogenesis in vitro. The observation of MVs' pro-angiogenic function came from the migration (scratch) assay of equine vascular endothelial cells (EVECs) and rat aortic ring assays, both performed in culture medium supplemented with MVs. It was revealed that exposure to MVs significantly promotes E-VEC migration relative to cells treated with control medium. Likewise, supplementation with MVs increased neovessel formation from aortic rings as compared with control, which showed minimal or lack of vessel formation. Sprouting of microvessels that was maximal after 7 days of culture and exhibited complete structural organization have led the authors to suggest that the MVs probably carry more than one angiogenic molecule [81]. Another study by Klymiuk et al. [82] provided further evidence of exosome secretion by equine ASCs. Although the authors did not examine the exosomes with regard to their function, their technical report described vesicle isolation from ASC supernatants and their characterization, providing an introduction to later therapeutic usage [82].

\section{Immunomodulatory Properties of ASCs}

One of the most clinically relevant properties of ASCs is their immunomodulatory capacity, as has been shown over the years in numerous experimental models [83-85]. In general, MSCs are widely described as being strongly immunosuppressive (reviewed in [86]). The ability to direct inhibition of the immune response by their paracrine factors might, in part, explain the reparative function of human ASCs observed in a variety of injury models [83]. To date, only a few studies have been conducted to investigate the immunomodulatory competence of farm animal ASCs [87, 88]. Holt et al. [88] showed that equine ASCs cultured in direct cell-cell contact with $\mathrm{T}$ cell-enriched peripheral blood mononuclear cells (PBMCs) caused inhibition of $\mathrm{T}$ cell proliferation at baseline and upon stimulation by alloantigen or mitogen phytohemagglutin (PHA). Moreover, treated ASCs secreted significantly more IL-6 and prostaglandin E2 $\left(\mathrm{PGE}_{2}\right)$ than stimulated T cells. In contrast, ASCs decreased the levels of pro-inflammatory cytokines, such as tumor necrosis factor alpha (TNF $\alpha)$ and 
interferon gamma (IFN $\gamma$ ) produced by activated T cells. It is noteworthy that this work compared the immunomodulatory properties of ASCs and MSCs derived from other tissues including bone marrow, umbilical cord blood, and umbilical cord tissue. In addition to the differences in NO production, the authors revealed qualitative similarities among all investigated types of MSCs. In a further study, the same authors found that the immunomodulatory properties of equine MSCs might be determined by tissue source. For instance, ASCs and umbilical cord tissue inhibited T cell proliferation through the induction of lymphocyte apoptosis while bone marrow and cord blood caused lymphocyte cell cycle arrest [88].

In order to study the immunomodulatory role of ASCs, Falomo et al. [89] demonstrated an interesting approach with the use of allogenic ASCs seeded on mare endometrial biopsy explants. Quantitative PCR analysis of explants incubated for 3 days with ASCs showed reduction of $I L-1 \beta, I L-10, T N F \alpha$, and $I L-1 R N$ mRNA, whereas expression of $I L-6$ and $I L-8$ mRNA increased. Considering the fact that IL- $1 \beta$ and $\mathrm{TNF} \alpha$ are recognized as pro-inflammatory cytokines, whereas IL-10 and IL-1RN show anti-inflammatory properties, these results suggest that ASCs might exert both positive and negative effects on endometrium in vitro [89].

With this background showing pro- and anti-inflammatory properties of equine ASCs, it can be presumed that immunosuppression is not an intrinsic, constitutive property of stem cells, but rather, the immunomodulatory abilities of ASCs are created by numerous independent stimuli. Studies performed by Bunnell et al. (reviewed in [86]) on human BMSCs led to the establishment of a new paradigm in MSC biology, which premised that MSCs, like monocytes, undergo polarization mediated by downstream Toll-like receptors (TLRs) into either a pro-inflammatory (MSC1) or an anti-suppressive reparative (MSC2) phenotype. This concept might explain the ability of ASCs to acquire disparate immune-modulating activities.

\section{ASC Culture Medium Supplementation}

Numerous studies in horses have examined the effect of medium supplementation in order to improve functional characteristics of ASCs. Del Blue et al. [70] showed that autologous platelet lysate (PL) significantly promoted proliferation of ASCs during $96 \mathrm{~h}$ of culture. To clarify, two different types of PL were tested in this study: rich PL that contained $41.0 \mathrm{mg} / \mathrm{mL}$ protein and poor PL in which the protein content reached $20.5 \mathrm{mg} / \mathrm{mL}$. Although medium supplementation with both PLs stimulated ASC proliferation, the rich PL exerted a greater effect on cell growth. Interestingly, according to the authors, protein concentration in both PLs was lower than that indicated in typical batches of fetal serum. In this line, the PL appeared to be an appropriate substitute for commercially available serum [70]. This study was further extended by Castro et al. [54] who found that application of vitamin $\mathrm{C}(0.1 \mathrm{mM})$ and PRP (5\% v/v; PRP) alone, but primarily in combination, promoted ASC differentiation toward osteogenic and chondrogenic lineages, as demonstrated by histological examination of calcium deposits and glycosaminoglycans (GAGs) and confirmed based on marker gene analysis [54]. In sheep, it has been observed that among different factors, including basic fibroblast growth factor (bFGF), bone morphogenetic protein 2 (BMP2), and NEL-like molecule 1 (NELL1), added to the osteogenic induction medium at four different doses $(1,10,50$, and $100 \mathrm{ng} / \mathrm{mL})$ each, only bFGF at the concentration $10 \mathrm{ng} / \mathrm{mL}$ enhanced osteogenic differentiation of ASCs [90]. Interestingly, Kalaszczynska et al. [91] demonstrated differences in osteogenic differentiation capacity between human and ovine BMSCs, and ASCs. Although mineralization of human cells was achieved in standard osteogenic medium supplemented with $\beta$-glycerophosphate, the commonly used organic source of phosphate ions, their ovine counterparts were unable to enter osteogenic induction upon the same treatment. Noticeable mineralization of the extracellular matrix of ovine BMSCs and ASCs was observed upon the addition of an inorganic source of phosphorus ions $\left(\mathrm{NaH}_{2} \mathrm{PO}_{4}\right)$ to the culture media.

\section{Three-Dimensional (3D) Scaffolds}

There is significant interest in taking advantage of biomaterials and $3 \mathrm{D}$ scaffolds in order to improve the desired functions of ASCs, such as prolonged survival, more rapid proliferation, or enhanced differentiation. Liu et al. [65] investigated the use of chitosan-coated plates for differentiation of pASCs into PILCs and found that chitosan accelerated cellular differentiation, and the cultures developed PILCs as early as day 3 , whereas on uncoated plates this process was delayed until day 12. Additionally, immunofluorescence staining revealed that chitosan upregulated insulin production on day 3 , compared to day 6 on regular plates. At the molecular level, it has been demonstrated that the scaffold substantially increases the expression of $\beta$-cell differentiation-associated transcripts, including $P A X-4, P d x-1$, glucokinase, and insulin. In another study, Kisiday et al. [72] showed that equine ASCs encapsulated in agarose or self-assembling peptide hydrogels responded to TGF- $\beta 1$ stimulation as reflected by accumulation of extracellular matrix (ECM) components such as proline, sulfate, and GAGs. It should also be noted that the efficiency of ECM deposition was higher for ASCs loaded into peptide hydrogels than for those seeded on agarose. Moreover, this effect was amplified in the case of BMSCs relative to ASCs [72]. There are also data demonstrating that collagen scaffolds support trilineage differentiation of horse ASCs and BMSCs [66]. More interestingly, the cells were entrapped within the scaffold and cultured in a perfusion 
bioreactor system, which provided a controlled environment for cell loading and resulted in higher seeding efficiency than with standard static cell loading methods. Therefore, this technique may be considered a tool for large-scale production of cell-scaffold constructs/implants for the purpose of regenerative medicine [66].

\section{Other Factors}

It should be emphasized that there are some alternative treatments to modify the behavior of ASCs. For example, Raabe et al. [36] demonstrated that extracorporeal shock-wave therapy (ESWT), which is used in equine veterinary practice for improving the healing of bone, tendon, or cartilage, exerts an effect on the cellular level and positively alters equine ASCs. Indeed, experimental conditions that relied on 9 pulses of 1000 shock waves and 3 pulses of 2000 shock waves led to significant increase in ASCs proliferation and contributed to more pronounced trilineage differentiation compared with the control untreated group. Moreover, ESWT treatment promoted expression of gap-junction protein connexin 43 (Cx43) mRNA. The mechanisms underlying the observed changes were related to activation of extracellular-signal-regulated protein kinases 1 and 2 (Erk1/2) [36]. Similarly, Maredziak et al. [35] exposed equine and canine ASCs to a static magnetic field (MF) with intensity of $\sim 0.5 \mathrm{~T}$. The study showed that equine, unlike canine, ASCs had a shorter doubling time than untreated control cells. Additionally, cells derived from equine adipose tissue demonstrated numerous MVs on their surface in response to MF. As shown in human ASCs, MVs carry a variety of bioactive molecules that enhance the recovery of damaged tissue $[92,93]$. Hence, these studies suggest that treatment with MF stimulates the secretory function of ASCs, supporting the paradigm that ASCs exert their effect on the surrounding environment via paracrine action. Due to the fact that damaged tissues are often characterized by limited oxygen or nutrient deprivation (reviewed in [94]), much attention has been paid to identifying strategies that lead to improving ASC survival in this environment. Along this line, preconditioning with hypoxia was shown to play a protective role in human stem cells, support their functions, and improve their therapeutic effect in vivo] [95-97]. Shell et al. [98] demonstrated that equine ASCs cultured in the presence of $3 \% \mathrm{O}_{2}$ showed reduced proliferation compared to normoxic control conditions $\left(21 \% \mathrm{O}_{2}\right)$. Furthermore, whereas hypoxia improved adipogenesis and chondrogenesis, the condition reduced osteogenic differentiation capacity [98].

\section{In Vivo Study with Domestic Animal ASCs}

Although laboratory rodents still remain the most significant and widely used experimental animals, large animals have become increasingly important in developing biomedical research. Considering the body size, specific anatomical and physiological characteristics, or the tendency to suffer from similar diseases as human (e.g., type I diabetes, hypertension, allergies, cancer, epilepsy, myopathies; reviewed in [99]), large animal species are more suitable to mimicking human clinical conditions. Moreover, from the perspectives of regenerative medicine and cell-based therapies, another important advantage of large animals is their relatively long life span, which allows monitoring of the long-term effects of a given therapy and answers questions regarding the benefits and potential obstacles of a treatment.

The selection of an appropriate animal model for translational research/cell-based therapy depends on a number of factors, including availability, ease of handling, anatomical and functional resemblance to humans, and specificity of the problem that the study aims to address. In view of current literature demonstrating the effect of MSCs on a broad range of diseases, there is considerable evidence indicating some preferences in the choice of the most suitable species for a study of interest (Fig. 2). For example, pigs have been extensively used to study the wound healing process due to the numerous similarities of pig skin to human skin, such as relatively thick epidermis, dense elastic fibers in the dermis, similar biochemical structure of collagen, sparse hair, and epidermal turnover of approximately 30 days $[113,114]$. Importantly, pig wound models have been regarded as the most appropriate to model cutaneous wound healing in humans (reviewed in [115]). In a review, Sullivan et al. [116] provided comparison of the data that documents wound therapies in different animal models and found that pig models were $78 \%$ consistent with human studies; this record exceeded that of other species, which overlapped with human data by only 53\%. In another review, Seaton et al. [115] presented an in-depth report of a generation of multiple pig wound-healing models and their use to study both normal and pathological wound healing, including chronic non-healing wounds, diabetic wounds, burns, wound infections, and hypertrophic scars. This confirms that pig models have been increasingly appreciated in the investigation of healing of wounds of numerous etiologies and that all have served as clinically relevant models. The second large research area in which pigs have often been used as a model is cardiovascular disease, as this species parallels favorably to human cardiovascular anatomy and physiology with respect to distribution of coronary arteries, ventricular performance, cardiac metabolism, electrophysiology, and collateralization after acute myocardial infarction [117]. In contrast, the horse is already established as an animal model for focal cartilage injuries and osteoarthritis (reviewed in $[118,119])$. An important advantages of horse joint models are their sheer size, which allows for easy manipulation and exploration, and cartilage thickness and composition, which share close similarities with human articular 


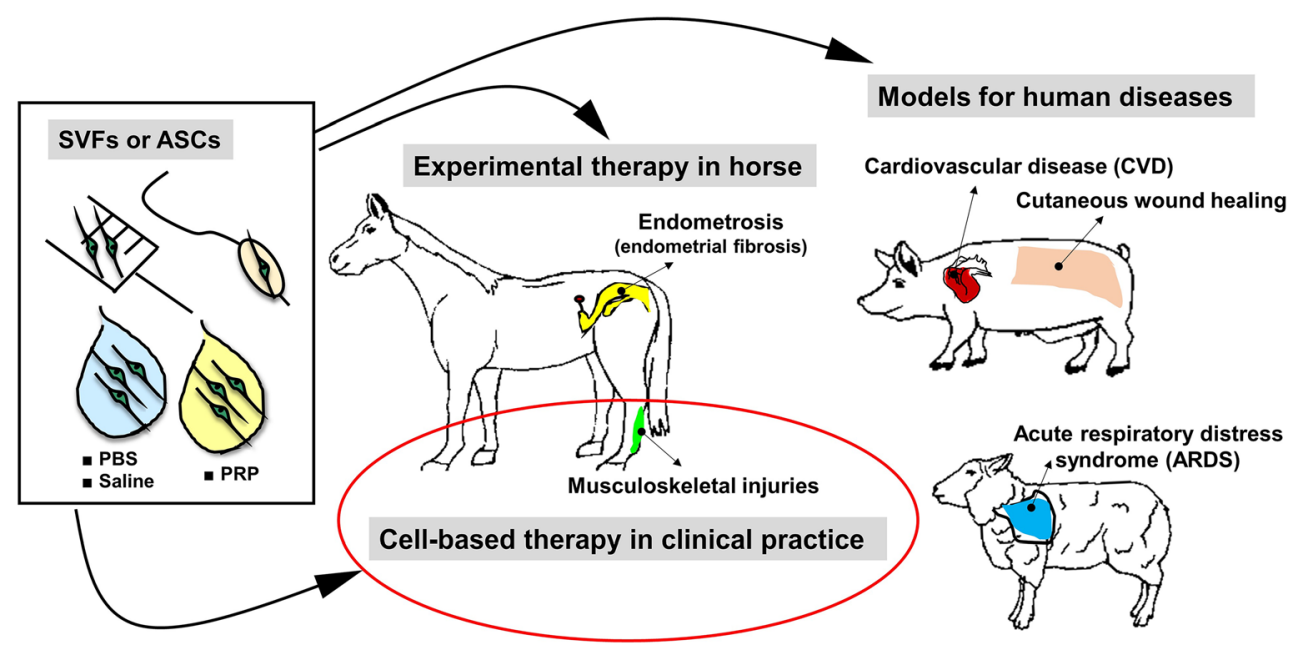

Fig. 2 Utilization of ASCs and/or SVFs in translational research with pig, horse, and sheep models of human disease, and therapeutic applications of these cells in veterinary practice. Routinely, ASCs/SVFs are suspended in phosphate-buffered saline (PBS), $0.9 \%$ sodium chloride (saline) or platelet-rich plasma (PRP). Different routes of administration of these cells are practiced, including intra-tissue or intravenous injections (musculoskeletal injury treatment, cutaneous wound healing, acute respiratory

cartilage [120]. The horse has also been shown to be an advantageous model of tendon and ligament injuries, due to the fact that many spontaneous injuries observed in horses are similar to those reported in human athletes (reviewed in [121]). Although a number of preclinical studies have investigated the use of ASCs in animal models of diseases, data on the application of ASCs in farm animals other than pigs and horses (e.g. sheep and cattle) are limited. Of note, Ihara et al. [52] used an ovine model of acute respiratory distress syndrome (ARDS) induced by smoke inhalation to estimate the efficacy of intravenously administrated ASCs. It has been shown that ASCs delivered at a dose of $2.0 \times 10^{8}$ cells, remarkably reduced pulmonary microvascular hyperpermeability, significantly ameliorating pulmonary gas exchange and improving the oxygenation index. Additionally, considering the fact that the treatment was well tolerated by animals, as negative hemodynamic changes did not occur, the study suggested that ASC-based therapy might provide a safe and efficient alternative to treat patients suffering from ARDS [52] [Table 2]. Although the use of cattle as a model system has provided a remarkable contribution toward the advancement of biomedical research (reviewed in $[122,123]$ ) there is a lack of published pre- and clinical reports specifically validating ASCs as a therapeutic means in this species. Nevertheless, existing studies demonstrating protocols of efficient ASC isolation from bovine fat, the in vitro approval of cell functionality, and the knowledge obtained from nonbovine large models, creates a path toward developing stem cell therapies in cattle $[43,50,53]$. Last, but not least, is the fact that while veterinary patients are increasingly recognized as critical translational models of human diseases, some cell- distress syndrome), intracoronary delivery using balloon angioplasty catheter (cardiovascular disease), or insemination catheter (endometrosis). Although ASCs/SVFs have been applied in pigs and sheep to treat induced injuries, to serve as models of human trauma, ASCs-based therapy in horses has been used in spontaneously occurring clinical cases of musculoskeletal injuries

based therapies are dedicated exclusively to providing cures for animal disease, with no secondary intention. MSC-related therapies have been documented as being used as instruments to address orthopedic conditions in horses [70]. Currently, a large proportion of pet owners and their veterinarians worldwide have turned to such treatment options, making stem cellbased therapies a reality in veterinary medicine.

Nevertheless, it should be noted that many authors focus their attention on the fact that in many cases stem cell therapies are applied in veterinary patients without relevant preclinical studies and are not controlled by regulatory agencies. This liberal approach has led to raising the general expectancy for regulations and guidelines to ensure standardization and quality assurance of cellular therapies being applied in veterinary practice (reviewed in $[124,125]$ ).

\section{Wound Healing in Skin}

With regard to large animal models, particularly pigs, ASCs and their potential to improve cutaneous wound healing have been investigated in several studies [23, 100-104] [Table 2]. James et al.] [101] performed a dose-response study of allogenic porcine ASCs delivered into four-centimeter circular full-thickness excisional wounds. They found that a high dose of ASCs $\left(3.0 \times 10^{6}\right.$ cells $\left./ \mathrm{cm}^{2}\right)$ at 2 weeks post-injection accelerated wound contraction, increased neodermal thickness, and enhanced neovascularization when compared with lower-dose ASCs and saline-injected control wounds. It should be emphasized that because PKH26-labeled fluorescent ASCs were used, it was possible to identify their transplantation pattern in the healed skin. ASCs, however, were integrated into the 
Table 2 Summary of in vivo application of ASCs ${ }^{\mathrm{a}}$ in experimental disease models and spontaneous clinical cases in pigs, mini pigs, horses and sheep

\begin{tabular}{|c|c|c|c|c|c|}
\hline Animal & Specific model & ASC treatment & Follow up & Outcome & References \\
\hline Pig & $\begin{array}{l}\text { Wound healing in diabetic } \\
\text { pigs (full-thickness circular } \\
\text { wounds) }\end{array}$ & $\begin{array}{l}\text { Allogeneic ASCs: } 5 \times 10^{6}, \\
1 \times 10^{7} \text {; Allogeneic } \\
\text { EC }^{\mathrm{b}} / \text { ASCs: } 5 \times 10^{6}, \\
1 \times 10^{7} ; \text { ASC-CM } \mathrm{CM}^{\mathrm{c}}: \text { topical } \\
\text { application in } 2 \mathrm{~mL} \text { serum-free } \\
\text { medium }\end{array}$ & $\begin{array}{l}\text { Up to } \\
28 \text { days }\end{array}$ & $\begin{array}{l}\text { Cellular therapy and topical application of } \\
\text { ASC-CM caused acceleration of } \\
\text { wound closure rates, increased } \\
\text { angiogenesis, and attenuated acute in- } \\
\text { flammation }\end{array}$ & {$[100]$} \\
\hline Pig & $\begin{array}{l}\text { Wound } \\
\text { healing (full-thickness } \\
\text { circular wounds) }\end{array}$ & $\begin{array}{l}\text { Allogeneic ASCs: } 3 \times 10^{6} / \mathrm{cm}^{2} \text {, } \\
\qquad 1 \times 10^{6} / \mathrm{cm}^{2}, 3 \times 10^{5} / \mathrm{cm}^{2}\end{array}$ & $\begin{array}{l}1 \text { and } \\
2 \text { weeks }\end{array}$ & $\begin{array}{l}\text { High-dose ASCs accelerate wound } \\
\text { contraction, enhance } \\
\text { neovascularization, and increase } \\
\alpha \text {-smooth muscle actin } \\
\text { expression;medium-dose improved } \\
\text { Col1:Col3 (collagen 1:collagen 3) ratio }\end{array}$ & [101] \\
\hline Pig & $\begin{array}{l}\text { Wound healing (deep } \\
\text { partial-thickness burn } \\
\text { wounds) }\end{array}$ & $\begin{array}{l}\text { Allogeneic ASCs: } 2 \times 10^{6} \text {; Allogenic } \\
\text { fat }\end{array}$ & $\begin{array}{l}\text { Up to } \\
10 \text { weeks }\end{array}$ & $\begin{array}{l}\text { Reduction in scar size; decreased } \\
\text { expression of } B A R X 2 \text { transcript, which } \\
\text { encodes protein involved in } \\
\text { myofibroblast migration and } \\
\text { differentiation;upregulation of } S P R Y-2 \\
\text { mRNA encoding protein involved in } \\
\text { FGF2 }{ }^{\mathrm{d}} \text { receptor ligand binding and } \\
\text { activation; diminished vessel presence }\end{array}$ & {$[102]$} \\
\hline $\begin{array}{l}\text { Mini } \\
\text { pig }\end{array}$ & $\begin{array}{l}\text { Wound } \\
\text { healing (partial-thickness } \\
\text { wounds produced by } \\
\text { dermatome) }\end{array}$ & $\begin{array}{l}\text { Allogeneic ASCs (or } \\
\text { BMSCs): } 1 \times 10^{6} \text {; Wounds were } \\
\text { dressed with bismuth gauze and } \\
\text { fibrin sealant }\end{array}$ & $\begin{array}{l}\text { Up to } \\
21 \text { days }\end{array}$ & $\begin{array}{l}\text { Improvement in scar cosmetic appearance } \\
\text { (vascularity, pigmentation, pliability, } \\
\text { and height) and faster } \\
\text { re-epithelialization compared to saline } \\
\text { controls }\end{array}$ & {$[23]$} \\
\hline Pig & $\begin{array}{l}\text { Delayed wound } \\
\text { healing (full-thickness } \\
\text { wounds made in irradiated } \\
\text { skin) }\end{array}$ & $\begin{array}{l}\text { Allogenic ASCs: } 4 \times 10^{6}\left(1.8 \times 10^{6}\right. \\
\left.\text { cells } / \mathrm{cm}^{2}\right) \text { in saline solution or } \\
\mathrm{PRP}^{\mathrm{e}}\end{array}$ & $\begin{array}{l}\text { Up to } \\
21 \text { days }\end{array}$ & $\begin{array}{l}\text { Faster re-epithelialization and increased } \\
\text { microvessel densities. However, the } \\
\text { healing enhancement depends on the } \\
\text { combination of ASCs and PRP, as nei- } \\
\text { ther ASCs nor PRP alone showed an } \\
\text { effect }\end{array}$ & [103] \\
\hline Pig & $\begin{array}{l}\text { Wound } \\
\text { healing (full-thickness } \\
\text { wounds) }\end{array}$ & $\begin{array}{l}\text { Allogenic ASCs: Topical application } \\
\text { of ASCs in PRP or PPP }\end{array}$ & $\begin{array}{l}\text { Up to } \\
21 \text { days }\end{array}$ & $\begin{array}{l}\text { Improvement in scar cosmetic appearance } \\
\text { and increase in microvascular density } \\
\text { in a group receiving ASCs+PRP; no } \\
\text { effect of ASCs on wound closure rate }\end{array}$ & [104] \\
\hline Pig & $\begin{array}{l}\text { Acute myocardial infarction } \\
\text { (AMI) induced by occlu- } \\
\text { sion of the mid } \mathrm{LAD}^{\mathrm{g}} \text { with } \\
\text { angioplasty balloon for } 3 \mathrm{~h}\end{array}$ & $\begin{array}{l}\text { Autologous SVFs: } 1.5 \times 10^{6} \text { cells } / \mathrm{kg} \\
\text { injected into the infarct artery }\end{array}$ & 8 weeks & $\begin{array}{l}\text { Functional improvement manifested by } \\
\text { reduction of myocardial perfusion } \\
\text { defect and increase in myocardial } \\
\text { salvage index and ejection } \\
\text { fraction. Structural improvement } \\
\text { reflected by increased wall thickness of } \\
\text { the infarct and border zone and } \\
\text { increased capillary density in the border } \\
\text { zone }\end{array}$ & {$[105]$} \\
\hline Pig & $\begin{array}{l}\text { AMI induced by occlusion of } \\
\text { the mid LAD with } \\
\text { angioplasty balloon for } \\
180 \text { min }\end{array}$ & $\begin{array}{l}\text { Autologous ASCs (or } \\
\text { BMSCs): } 2 \times 10^{6} \text { in } 4 \mathrm{~mL} \text { PBS }\end{array}$ & 4 weeks & $\begin{array}{l}\text { Reduction of absolute and relative } \\
\text { perfusion defect,increased left } \\
\text { ventricular ejection fraction,increased } \\
\text { relative thickness of the ventricular wall } \\
\text { in the infarction area, andimproved } \\
\text { vascular density of the border zone }\end{array}$ & {$[106]$} \\
\hline Pig & $\begin{array}{l}\text { AMI induced by placing an } \\
\text { angioplasty catheter into the } \\
\text { mid LAD for } 90 \mathrm{~min}\end{array}$ & $\begin{array}{l}\text { Autologous ASCs: } 1.6 \pm 1.1 \times 10^{7} \\
\text { intracoronary } \\
\text { delivery; } 2.3 \pm 0.8 \times 10^{7} \\
\text { transendocardial delivery }\end{array}$ & 3 weeks & $\begin{array}{l}\text { Increased vascular density following } \\
\text { intracoronary ASC administration }\end{array}$ & {$[107]$} \\
\hline $\begin{array}{l}\text { Mini } \\
\text { pig }\end{array}$ & $\begin{array}{l}\text { AMI induced by placing an } \\
\text { angioplasty catheter into the } \\
\text { mid LAD for } 120 \mathrm{~min}\end{array}$ & $\begin{array}{l}\text { ASCs expressing green fluorescent } \\
\text { protein (GFP): } 2.13 \pm 0.42 \times 10^{8} \\
\text { transendocardial delivery }\end{array}$ & 3 months & $\begin{array}{l}\text { Increased angiogenesis and } \\
\text { vasculoneogenesis andimprovement in } \\
\text { heart remodeling (increased expression } \\
\text { of TIMP }{ }^{\mathrm{h}} 1,2 \text { but decreased MMP } 2 \\
\text { activity) }\end{array}$ & {$[108]$} \\
\hline Horse & $\begin{array}{l}\text { Tendonitis (spontaneously } \\
\text { occurring) }\end{array}$ & $\begin{array}{l}\text { Allogenic ASCs: Delivered in } \\
\text { association with PRP or PPP }\end{array}$ & $\begin{array}{l}\text { Over } \\
23 \text { weeks }\end{array}$ & $\begin{array}{l}\text { Of the } 16 \text { treated horses, } 14 \text { recovered and } \\
\text { regained activity }\end{array}$ & {$[70]$} \\
\hline Horse & & & 24 months & & [109] \\
\hline
\end{tabular}


Table 2 (continued)

\begin{tabular}{|c|c|c|c|c|c|}
\hline Animal & Specific model & ASC treatment & Follow up & Outcome & References \\
\hline & $\begin{array}{l}\text { Superficial digital flexor } \\
\text { tendonitis } \\
\text { (SDFT) (spontaneously } \\
\text { occurring) }\end{array}$ & $\begin{array}{l}\text { Allogenic ASCs: } 2.0 \times 10^{6} \text { in } 2-6 \mathrm{~mL} \\
\text { of PRP }\end{array}$ & & $\begin{array}{l}\text { Improved echogenicity of the tendon } \\
\text { structuresstarting from } 60 \text { to } 90 \text { days } \\
\text { after treatment shown by ultrasound } \\
\text { images;functional recovery and return } \\
\text { to previous level of activity observed in } \\
89.5 \% \text { of the horses, while re-injury } \\
\text { rate occurred in } 10.5 \% \text { animal patients }\end{array}$ & \\
\hline Horse & $\begin{array}{l}\text { SDFT (spontaneously } \\
\text { occurring) }\end{array}$ & ASCs: $1.0 \times 10^{6}$ in $5-10 \mathrm{~mL}$ of PRP & $\begin{array}{l}\text { Up to } \\
9 \text { months }\end{array}$ & $\begin{array}{l}\text { Increase in echogenicity, intralesional, } \\
\text { and an array of grade } 2 \text { according to the } \\
\text { tendon fibers by Reef at } 30 \text { days after } \\
\text { transplantation;the alignment of tendon } \\
\text { fibers reached grade } 1 \text { according to } \\
\text { Reef with decrease in the size of the } \\
\text { lesion after } 60 \text { days; full alignment of } \\
\text { tendon fibers at } 120 \text { days,seven of nine } \\
\text { horses resumed their normalathletic } \\
\text { activity }\end{array}$ & {$[110]$} \\
\hline Horse & $\begin{array}{l}\text { Endometrosis (spontaneously } \\
\text { occurring) }\end{array}$ & $\begin{array}{l}\text { ASCs fluorescently labeled: } 2.0 \times 10^{7} \\
\text { in } 20 \mathrm{~mL} \text { of sodium chloride } 0.9 \%\end{array}$ & $\begin{array}{l}\text { Up to } \\
21 \text { days }\end{array}$ & $\begin{array}{l}\text { Detection of labeled ASCs in both uterine } \\
\text { horns and uterine body;cells homed } \\
\text { into periglandular space and } \\
\text { uterineglands }\end{array}$ & {$[111]$} \\
\hline Horse & $\begin{array}{l}\text { Endometrosis (spontaneously } \\
\text { occurring) }\end{array}$ & $\begin{array}{l}\text { Allogenic ASCs fluorescently } \\
\text { labeled: } 2.0 \times 10^{7} \text { in } 20 \mathrm{~mL} \text { of } \\
\text { sodium chloride } 0.9 \%\end{array}$ & $\begin{array}{l}\text { Up to } \\
60 \text { days }\end{array}$ & $\begin{array}{l}\text { Diminished expression of vimentin, } \\
\alpha \text {-SMA }{ }^{\mathrm{j}} \text { and cytokeratin } 18 \text { that } \\
\text { correlated with positive histological } \\
\text { changes in endometrial biopsy samples }\end{array}$ & {$[112]$} \\
\hline Sheep & $\begin{array}{l}\text { Acute respiratory distress } \\
\text { syndrome } \\
\text { (ARDS) (induced by } \\
\text { smoke inhalation) }\end{array}$ & $\begin{array}{l}\text { ASCs: } 2.0 \times 10^{8} \text { in } 200 \mathrm{~mL} \text { of } \\
\quad \text { PlasmaLyteA }\end{array}$ & 48 hours & $\begin{array}{l}\text { Reduction of pulmonary microvascular } \\
\text { hyperpermeability;increased } \\
\text { oxygenation index and pulmonary gas } \\
\text { exchange }\end{array}$ & {$[52]$} \\
\hline
\end{tabular}

${ }^{\mathrm{a}} A S C$ s adipose derived stromal/stem cells, ${ }^{\mathrm{b}} E C$ endothelial cells, ${ }^{\mathrm{c}} A S C-C M$ adipose stem cell conditioned medium, ${ }^{\mathrm{d}} F G F 2$ Fibroblast growth factor 2 , ${ }^{\mathrm{e}} P R P$ platelet-rich plasma, ${ }^{\mathrm{f}} P P P$ platelet-poor plasma, ${ }^{\mathrm{g}} L A D$ mid-left anterior descending artery, ${ }^{\mathrm{h}}$ TIMP tissue inhibitor of metalloproteinases, ${ }^{\mathrm{i}} M M P$ matrix metalloproteinase, ${ }^{\mathrm{j}} \alpha-S M A$ smooth muscle actin alpha

deep neodermis at 1 week, but the signal weakened at 2 weeks post-delivery [101]. Perhaps this indicated paracrine signaling from injected ASCs, as it has been extensively reported in terms of wound healing in rodent models $[92,126]$.

As mentioned earlier, there are substantial arguments favoring some special pretreatment with ASCs, or the use of ASCs combined with numerous factors that might augment their engraftment and functions, and lead to potential ASC amplification to improve wound healing. In the work performed by Blanton et al. [104], ASCs were mixed with PRP or platelet-poor plasma (PPP), and then applied to fullthickness excisional wounds made on the dorsal skin of female Yorkshire pigs. Gross appearance at 3 weeks after wounding demonstrated a trend toward improved cosmetics in all experimental groups; however, only ASCs applied together with PRP exhibited significant improvement in the qualitative scoring scale. Likewise, vessel densities increased in samples receiving ASCs in association with PRP. This in vitro approach demonstrated an increased release of vascular endothelial growth factor (VEGF) from combined ASC and PRP cultures, indicating that ASCs enhance the process of healing, in part via contribution to revascularization, when provided with a fibrin matrix that is rich in complementary trophic factors [104]. In a separate study, Hadad et al. [103] employed a similar ASC delivery strategy to treat wounds in irradiated skin in a delay model of full-thickness injury of Yorkshire pigs. In this particular injury model, pigs received a single 20-Gy radiation dose to an $18 \times 40-\mathrm{cm}$ field of the dorsal skin. Seven weeks after the treatment, wounds were created in the irradiated area and subsequently ASCs suspended in PRP (or both treatments separately) were delivered to the wounds. Results revealed that the combination of ASCs and PRP was superior to all treatments in accelerating the rate of wound contraction and re-epithelialization. Furthermore, based on an immunohistological examination of $\alpha$-smooth muscle actin ( $\alpha$-SMA) expression in biopsy specimens collected at 21 days post-injury, a significant increase was observed in the microvessel density in healed wounds that had been treated with the combination of ASCs and PRP, compared to those treated with saline solution [103].

Application of ASCs was also examined in a pig model displaying some wound healing pathologies including hypertrophic scarring [102] and diabetic wounds [100]. Rapp et al. [102] adapted a burn model of domestic pigs to determine 
whether autologous ASCs or intradermal delivery of autologous fat improved the process of healing by reduction of hypertrophic scar formation. In this model, mature wounds at 10 weeks post-injury were treated with saline, autologous ASCs, or fresh lipoaspirate. Scars injected with autologous fat or ASCs showed significant reduction in volume as compared with the saline-treated and unburned control group. However, neither ASCs nor lipoaspirate showed significant improvement in biochemical properties of scars 10 weeks post-treatment. In addition, while erythema was increased in all treated animals, the increase was statistically significant for scars that had been treated with ASCs or fat. On the other hand, RNA sequencing data demonstrated that, among 148 identified genes, as many as 99 showed significant differences in their expression across the treated group, compared with untreated scars. Of particular interest, genes with significantly altered expression upon ASC or lipoaspirate delivery, such as $B A R X 2$ and $S P R Y-2$, are known to contribute myofibroblast function. These molecular results provided strong indications that the treatment of hypertrophic scars with ASCs or fresh adipose tissue may lead to changes in regulatory pathways involved in wound healing dynamics that attenuated formation of hypertrophic scars [102].

Given the fact that impaired healing of diabetic wounds is a serious medical problem worldwide, and that so far none of the current research using mouse models has provided preventative or therapeutic cues, there is significant interest in finding ways to treat this type of injury. A porcine model that addresses this clinical problem was presented by Irons et al. [100] and relies on streptozotocin-induced diabetes followed by full-thickness excisional wounding of the back skin in female Yorkshire pigs. In this study, wounds were either injected with ASCs or endothelial-cell-differentiated ASCs (EC/ASCs) at a dose of 5 or $10 \times 10^{6}$ cells, or they received topical application of conditioned medium from ASC (ASC/ $\mathrm{CM}$ ) or human umbilical vein endothelial cells HUVEC (HUVEC/CM) cultures. Of note, wounds subjected to cellular treatment received a repeat injection of one half of the initial dose on day 15, whereas those assigned to the topical CM therapy were covered with fresh CM every 3 days. The results showed an increase in wound closure rates upon treatment with both cells and $\mathrm{CM}$ at various time points during the post-wounding period of 28 days. Histological examination of tissue sections revealed a decrease in the acute inflammation scores in wounds receiving cell-based and CM therapy; however, the chronic inflammation scores were similar between the treated and control groups. Furthermore, no statistically significant differences were observed in the expression of angiogenic (CD31, platelet-derived growth factor [PDGF]), endothelial nitric oxide synthase [eNOS]) and proinflammatory (TNF $\alpha$, IL-1 $\beta$ ) genes at 28 days post-treatment. However, at the protein level, a significant decrease in TNF $\alpha$ was found in the wounds treated with $\mathrm{ASC} / \mathrm{CM}$ and $\mathrm{EC} / \mathrm{CM}$.
Overall, despite the fact that the general findings of these studies remain partially inconclusive and reinforce the need for further research using this particular wound model, there is strong evidence that employing CM provides a promising method to bypass the need to deliver ASCs to improve the healing outcome [100].

\section{Cardiovascular Disease}

Cardiovascular disease (CVD) is the primary cause of morbidity and mortality worldwide with a recognized set of risk factors including obesity and sedentary lifestyle [127, 128]. The significant number of deaths associated with CVD result from heart failure due to ischemic events such as myocardial infarction (MI). Because the heart demonstrates limited reparative capacity, the restoration of cardiac function after an MI is challenging [129]. This is a major reason why the current revascularization procedures have provided modest regeneration effects, and it reinforces the need for exploration of alternative therapies for treatment of damaged myocardium (reviewed in [130]). Recently, numerous preclinical studies involving pigs have been conducted to analyze the efficacy, safety, and behavior of ASCs in the treatment of acute myocardial infarction (AMI) [105-108] [Table 2]. Valina et al. [106] induced an experimental AMI model by 3-h balloon angioplasty of the mid-left anterior descending artery (LAD), and then using the same balloon catheter, they performed an intracoronary injection of $2 \times 10^{6}$ autologous cells (ASCs or BMSCs at a dose of $6 \times 10^{4}$ cells $/ \mathrm{kg}$ ) in $4 \mathrm{~mL}$ phosphate-buffered saline (PBS). Four weeks after the onset of the experiment, nuclear cardiac imaging revealed significant functional and structural coronary improvements resulting from ASC and BMSC treatment. Specifically, both cell types increased absolute myocardial salvage as compared to the control PBS-treated group. Significant improvements in the motion of the left ventricular wall and its relative thickness in the infarction area were observed in the ASC-treated group. The presence of ASCs also led to increased vascular density in the border zone between infarcted and non-infarcted myocardium that was assessed based on immunofluorescence staining of von Willebrand factor (vWF). Delivery of BMSCs had a similar effect on capillary density; however, the data did not reach statistical significance [106]. The same pattern of superior cardiac functional recovery was seen when freshly isolated SVFs, instead of their cultured counterparts, were applied to the pig AMI model [105]. Indeed, Alt et al. found that at 8week follow up to repetitive intracoronary injections of a suspension of uncultured SVFs containing $1.5 \times 10^{6}$ cells $/ \mathrm{kg}$ a $20 \%$ reduction of myocardial perfusion defect was observed, an increase in both myocardial salvage index and ejection fraction, relative to control animals [105]. Given that there is still much debate regarding the question of whether ASCs or 
SVFs would be more beneficial in therapy, the urgent need to conduct comparable studies seems reasonable.

In the case of ischemic heart injury, as in other types of tissue-specific injury, the ASC delivery route has been tested. Rigol et al. [107] compared the effect of intracoronary and transendocardial administration of autologous ASCs in a porcine model of AMI. At 3 weeks post-treatment, engrafted cells were localized in the border zone of the infarct and close to vessels, regardless of the pathway of their delivery. Similarly, in both experimental groups immunofluorescence analysis demonstrated that some of the implanted cells expressed $\alpha$ SMA, the marker of smooth muscle cells. However, the total vessel count using histochemical staining for vWF and $\alpha$ SMA demonstrated that intracoronary infusion was more effective in increasing neovascularization than ASCs injection directly into the affected area [107]. Consistent with this study, Fotuhi et al. [131] adapted a pig AMI model to investigate the effect of intravenous ASCs delivery on heart electrophysiology. As an analogue to clinical practice, at the 8week follow up, the animals underwent a programmed stimulation protocol for the induction of ventricular arrhythmias. The results indicated that the cell administration method via intravenous infusion did not lead to acute ventricular arrhythmia, bradycardia, or conduction block, so the ASC-based therapy showed a lack of electrophysiological consequences in the porcine AMI model.

Obtaining a sustained effect of cell-based therapy also requires optimization of the timing of cell administration. Substantial cardiac differences were observed between pigs that received ASCs at $15 \mathrm{~min}$ and at 7 days after AMI induction [132]. Immunostaining of VEGF, $v W F$, and $\alpha$-SMA revealed a significantly higher number of vessels in the infarct border zone in samples collected from animals treated with ASCs 15 min after reperfusion than in pigs who received ASCs 7 days after AMI. Moreover, this study also provided some important data regarding the host immune response, as allogenic ASCs were applied to treat the cardiac artery following reperfusion. At the 3-week follow up, the percentage of area occupied by $\mathrm{CD} 3+$ cells was significantly greater in a group that was administered ASCs 15 min after coronary reperfusion, compared with those treated 7 days later. In addition, the formation of donor-specific antibodies in $33.3 \%$ of animals treated with ASCs supported the conclusion that allogenic ASCs are not absolutely immune-privileged [132].

A remarkable advantage of the use of large, relatively longlived animals is the ability to have prolonged time for observation of a therapeutic outcome and possible side effects. In the work performed by Mazo et al. [108], the effect of transendocardial injection of ASCs into a minipig model of MI was analyzed 3 months after transplantation. Several significant long-lasting improvements in cardiac function were observed compared to the medium control, including increases in cardiac contractility and left ventricular ejection fraction (LVEF) and prevention of worsening ventricle geometry, manifested by the significant decrease in end-systolic diameter (ESD) and both end-diastolic (EDV) and endsystolic (ESV) volume. Afterwards, tissue fibrosis (collagen content), vessel density, and myocyte hypertrophy in the border zone of the infarct were measured based on quantification of Sirius Red staining, $\alpha$-SMA, lectin-I, and laminin, respectively. The results revealed a reduction in fibrosis and cardiomyocyte hypertrophy, accompanied by a significant increase in blood vessel density. Particularly interesting was the observation that ASC transplantation provided an increase in the number of vessels positive for matrix metalloproteinase (MMP) inhibitors (TIMPs), such as TIMP1 and TIMP2, in the infarct border zone. Additionally, a decrease in the activity of MMP2 was found by zymography in serum collected from ASC-treated pigs. These findings clearly show that ASCs might participate in the correction of the imbalance in the MMP/TIMP system that is observed after MI; therefore, they prevent improper remodeling of the heart and suppress scar tissue formation [108]. It is noteworthy that the authors reported a lack of long-term cell engraftment that, analogous to other studies, indicates that the primary mechanism exerted by ASCs on damaged tissue relies on cell secretory functions $[133,134]$.

\section{Musculoskeletal System}

Much of the interest in the veterinary field has focused on the use of ASCs for musculoskeletal injuries such as tendon, bone, and cartilage lesions (reviewed in [135]) [Table 2]. In the vast majority of cases, these defects are associated with failure to return to the previous levels of physical activity along with considerable rates of re-injury, which in horses ranges from $16 \%$ to $53 \%$ [136, 137]. In practice, the orthopedic injuries provide career-ending conditions in the sport animals.

A major cause of injury in racehorses and in horses used for any discipline is tendinitis of superficial digital flexor tendon (SDFT) [110]. Following injury, the tendon tissue is spontaneously repaired by scar tissue formation; however, the scar is functionally deficient and characterized by lower mechanical strength, reduced elasticity, and increased stiffness [110]. In addition, the healing of tendons is painful, long-lasting, and associated with high costs of treatment. The reported duration of recovery period is between 9 and 14 months and can be even prolonged up to18 months or longer [137-139]. These common complications provide important consequences for the animal in terms of reduced performance $[110,139]$.

Considering the fact that in several published works cell therapies using MSCs from distinct sources, including bone marrow and umbilical cord blood, have shown promising results in the context of musculoskeletal disease, currently there is growing interest in using autologous ASCs as an alternative 
therapeutic option in clinical practice [140,141]. Despite the fact that in veterinary medicine, cell-based therapy is a clinical reality, within the equine orthopedic field, ASCs have been used primarily in experimentally induced tissue defects with a very limited number of reports describing spontaneously occurring clinical cases. An initial study by Del Bue et al. [70] evaluated the clinical effect of delivery of allogeneic ASCs in association with autologous PRP into naturally occurring SDFT lesions in equine athletes. Although the report lacks details of the experimental procedure and no control (untreated) animals were included in the trial, they observed satisfactory recovery at more than 23 weeks follow up and return to activity in 14 of 16 treated horses [69]. Likewise, Ricco et al. [109] showed short- and long-term outcomes (0-1 and 24 months, respectively) of 19 clinical cases of horses affected by acute or sub-acute SDFT that received allogenic ASCs combined with autologous PRP used as a cell carrier. Each lesion underwent a single injection of $2-6 \mathrm{~mL}$ cell suspension $\left(2.0 \times 10^{6}\right.$ cells $\left./ \mathrm{mL}\right)$ based on the lesion size. No detrimental effects that could manifest by acute tendon reaction, lameness, local swelling, or heat were found in the short term after cell transplantation. Furthermore, long-term ultrasonographic examination of the tendon revealed lack of abnormal tissue outgrowth within and around the ASC implantation site. This evidence of improved healing was supported by ultrasound images demonstrating greater echogenicity of the tendon structures emerging 60-90 days after treatment. Equally important, at 24 months follow up, 17 of 19 horses (89.5\%) regained their previous activity [109]. In another project, Guercio et al. [110] used $1.0 \times 10^{6}$ cells in $5-10 \mathrm{~mL}$ of PRP for a treatment of veterinary patients with spontaneous and acute SDFT in the forelimb. Consistent with the aforementioned studies, in this work the authors indicated at 3 months post-treatment some benefits related to tissue organization, based on ultrasound analysis demonstrating that characteristics indicative of a repair process resulted in formation of tissue morphologically comparable, in terms of size and alignment of the fibers, to healthy tissue. Finally, this investigation showed that 7 of 9 horses resumed their normal performance after several months of ASC transplantation [110]. However, it should be said that in the studies discussed here, the stem cell-based therapies were accompanied by rehabilitative physiotherapy, which provides essential support for the proper remodeling of the tendon and leads to restoring tissue functionality (reviewed in [142]). Thus, reported improvements in the health of equine patients might be attributed, at least in part, to the progressive rehabilitation programs. In addition, such clinical studies do not provide sufficient conclusions about the outcome of ASC therapy, primarily due to the small number of animals treated and lack of controls. On the other hand, in contrast to designed in vivo studies/trials that mainly involve selective, homogenous groups of animals, the significant advantage of such clinical cases is that they comprised spontaneous lesions in animals heterogeneous for age, sex, diet, and activity, and hence, the therapeutic results obtained represent a broad range of naturally occurring variables, and in clinical practice this allows for better adjustment of therapeutic procedures to individual clinical situations. Nevertheless, numerous studies have demonstrated the use of animals as a model for diseases with experimentally induced orthopedic lesions [143, 144]. In some of these studies, the therapeutic potential of ASCs is demonstrated by less inflammatory infiltrates to the affected tissue, increased blood flow, or well defined collagen-fiber organization compared to the untreated control group [143, 144]. Therapeutic benefits from application of stem cell types in horses are reviewed in greater detail by Shojaee [22] and De Schauwer [145].

\section{Endometrosis}

ASCs can be considered a promising candidate for cell therapies in equine endometrosis, a chronic degenerative condition of the endometrium [Table 2] [111, 112]. Endometrosis is defined as active or inactive fibrosis around the endometrial glands and in the stroma that is often associated with pathological changes in the endometrial glands within fibrotic foci [146, 147]. Equine endometrosis causes alterations in endometrial function manifested by changes in its histology, ultimately leading to changes in the uterine microenvironment, ovarian cycle, and early pregnancy dysfunction [148-150]. Endometrial fibrosis is a serious problem in horse reproduction and poses a great economic loss to the horse-breeding industry. Currently, no effective treatment is available for this condition. Mambelli et al. [111] transplanted in utero $2 \times 10^{7}$ fluorescence-labelled mare ASCs $\left(1 \times 10^{7}\right.$ cells in $10 \mathrm{~mL} 0.9 \%$ sodium chloride per each uterine horn) using a simple technique, similar to artificial insemination. The cells were detected in uteri at 7 and 21 days post-delivery and widely distributed in the glandular and periglandular area. At the 60-day follow up, there was no fluorescent signal detected in the uterine specimens. Having adapted this experimental procedure, the same group found in a separate study that allogenic ASCs induced early remodeling of endometrial tissue [112]. This process was manifested by the changes in the expression profile of endometrosis-associated proteins such as laminin, vimentin, Ki67 antigen, $\alpha$-SMA, and cytokeratin 18 (CK18). Indeed, upon ASCs delivery no co-expression of vimentin and CK18 was observed, and expression of $\alpha$-SMA was no longer observed at day 7 post-transplantation. Moreover, the number Ki-67-positive cells was significantly higher in animals treated with ASCs in comparison with untreated mares [112]. These unique studies are promising for the development of therapy to treat equine endometrosis. However, particularly interesting from the perspective of the present review is the fact that the authors used cells that had been cryopreserved in liquid nitrogen for two years and, after thawing, were directly applied to the animals without additional cultivation in vitro [112]. This approach clearly 
indicates feasibility of cryopreserved ASCs and advocates for their availability as an off-the-shelf product that will allow veterinarians to use them directly at the point of care.

\section{Conclusions and Future Perspectives}

This review demonstrates the current status of knowledge in terms of isolation techniques, culture, and multilevel characteristics of ASCs from farm animals, with particular attention focused on pigs and horses. Moreover, we provide a perspective on the general principles of ASC-based therapy in pig and horse models of human diseases, as well as highlighting the importance of using animal ASCs in veterinary practice. Although employing large animals for research on ASC therapeutic application generates higher costs due to animal size and husbandry needs compared to smaller laboratory animal models, their importance in the field of human diseases is evident as they have greater predictive ability. Thus, the ability to apply human-like settings to animal models increases the chances of bench findings translating to effective treatments.

It is important to recognize and appreciate the fact that the exploration of cellular therapies with the use of large animals can be valuable in establishing alternative medical approaches needed in both preclinical animal models of human diseases and for treating a wide range of conditions that affect animals. As we have discussed, the multitude of different protocols for ASC isolation and the diversity of their delivery routes provide evidence of how much interest in ASC-based therapy in farm animals exists today. However, there are still many issues that need to be addressed when considering ASC-based therapy. First of all, the mechanisms of action through which ASCs enhance healing or attenuate disease are incompletely understood. Although the beneficial properties of ASCs are shown to be related to their immune suppression, anti-inflammatory, and pro-angiogenic roles, knowledge about the specific pathways through which ASCs achieve their pro-repair/ pro-regenerative goals needs substantial research effort. Second, further investigations are required to standardize the protocols of the cell acquisition and therapy model in order to ensure safety, efficacy, and consistency for ASC therapy in animal patients. Currently, there are a multitude of different protocols with regard to patient vs. donor source, cell isolation technique, cell culture technique, MSC activation status, MSC dose, and route of administration, making it difficult to compare and choose the most optimal direction of ASC therapeutic development. The selection of the best suited method would guarantee good cell survival, wide distribution, and successful homing of cells in injured tissues, and finally, it must lead to satisfactory therapeutic outcome. Thirdly, in contrast to the slower translation of cellular therapies in human medicine, in the veterinary field such treatments have been rapidly commercialized from experimental models to mainstream clinical practice. Hence, the use of ASCs in veterinary practice requires strict regulatory procedures to ensure efficacy and safety of stem cell-based product applications.

There is no doubt that the use of ASC therapy in veterinary practice has incredible potential in advancing cure options for domestic animals. However, we should be aware of the limitations regarding these therapies, and more in-depth research is necessary to fully understand the potential of ASCs.

Acknowledgments We are grateful to MSc Wiktor Zieliński from University of Warmia and Mazury in Olsztyn for the graphical illustration of livestock animals displayed in the graphical abstract and in Fig. 2.

Funding This work was supported by the National Science Centre, Poland, grant SONATA13, no 2017/26/D/NZ5/00556.

\section{Compliance with Ethical Standards}

Conflict of Interest The authors report no conflicts of interest.

Open Access This article is licensed under a Creative Commons Attribution 4.0 International License, which permits use, sharing, adaptation, distribution and reproduction in any medium or format, as long as you give appropriate credit to the original author(s) and the source, provide a link to the Creative Commons licence, and indicate if changes were made. The images or other third party material in this article are included in the article's Creative Commons licence, unless indicated otherwise in a credit line to the material. If material is not included in the article's Creative Commons licence and your intended use is not permitted by statutory regulation or exceeds the permitted use, you will need to obtain permission directly from the copyright holder. To view a copy of this licence, visit http://creativecommons.org/licenses/by/4.0/.

\section{References}

1. Friedenstein, A. J., Petrakova, K. V., Kurolesova, A. I., \& Frolova, G. P. (1968). Heterotopic of bone marrow. Analysis of precursor cells for osteogenic and hematopoietic tissues. Transplantation, 6 , 230-247.

2. Pittenger, M. F., Mackay, A. M., Beck, S. C., Jaiswal, R. K., Douglas, R., Mosca, J. D., Moorman, M. A., Simonetti, D. W., Craig, S., \& Marshak, D. R. (1999). Multilineage potential of adult human mesenchymal stem cells. Science, 284, 143-147.

3. Zuk, P. A., Zhu, M., Mizuno, H., Huang, J., Futrell, J. W., Katz, A. J., Benhaim, P., Lorenz, H. P., \& Hedrick, M. H. (2001). Multilineage cells from human adipose tissue: Implications for cell-based therapies. Tissue Engineering, 7, 211-228.

4. Angelone, M., Conti, V., Biacca, C., Battaglia, B., Pecorari, L., Piana, F., Gnudi, G., Leonardi, F., Ramoni, R., Basini, G., Dotti, S., Renzi, S., Ferrari, M., \& Grolli, S. (2017). The contribution of adipose tissue-derived mesenchymal stem cells and platelet-rich plasma to the treatment of chronic equine laminitis: A proof of concept. International Journal of Molecular Sciences, 18, 2122.

5. Zuk, P. A., Zhu, M., Ashjian, P., De Ugarte, D. A., Huang, J. I., Mizuno, H., Alfonso, Z. C., Fraser, J. K., Benhaim, P., \& Hedrick, M. H. (2002). Human adipose tissue is a source of multipotent stem cells. Molecular Biology of the Cell, 13, 4279-4295. 
6. Kern, S., Eichler, H., Stoeve, J., Kluter, H., \& Bieback, K. (2006). Comparative analysis of mesenchymal stem cells from bone marrow, umbilical cord blood, or adipose tissue. Stem Cells, 24, 1294-1301.

7. Mohamed-Ahmed, S., Fristad, I., Lie, S. A., Suliman, S., Mustafa, K., Vindenes, H., \& Idris, S. B. (2018). Adipose-derived and bone marrow mesenchymal stem cells: A donor-matched comparison. Stem Cell Research \& Therapy, 9, 168.

8. Musina, R. A., Bekchanova, E. S., \& Sukhikh, G. T. (2005). Comparison of mesenchymal stem cells obtained from different human tissues. Bulletin of Experimental Biology and Medicine, 139, 504-509.

9. Sakaguchi, Y., Sekiya, I., Yagishita, K., \& Muneta, T. (2005). Comparison of human stem cells derived from various mesenchymal tissues - superiority of synovium as a cell source. Arthritis and Rheumatism, 52, 2521-2529.

10. Liu, T. M., Martina, M., Hutmacher, D. W., Hui, J. H. P., Lee, E. H., \& Lim, B. (2007). Identification of common pathways mediating differentiation of bone marrow- and adipose tissue-derived human mesenchymal stem cells into three mesenchymal lineages. Stem Cells, 25, 750-760.

11. Bukowska, J., Alarcon Uquillas, A., Wu, X., Frazier, T., Walendzik, K., Vanek, M., Gaupp, D., Bunnell, B. A., Kosnik, P., Mehrara, B., Katz, A. J., Gawronska-Kozak, B., \& Gimble, J. M. (2020). Safety and efficacy of human adipose-derived stromal/ stem cell therapy in an Immunocompetent murine pressure ulcer model. Stem Cells and Development, 29, 440-451.

12. Storti, G., Scioli, M. G., Kim, B. S., Orlandi, A., \& Cervelli, V. (2019). Adipose-derived stem cells in bone tissue engineering: Useful tools with new applications. Stem Cells International, 2019, 3673857.

13. Veronesi, F., Maglio, M., Tschon, M., Aldini, N. N., \& Fini, M. (2014). Adipose-derived mesenchymal stem cells for cartilage tissue engineering: State-of-the-art in in vivo studies. Journal of Biomedical Materials Research. Part A, 102, 2448-2466.

14. Rodbell, M. (1964). Metabolism of isolated fat cells. I. Effects of hormones on glucose metabolism and lipolysis. Journal of Biological Chemistry, 239, 375-380.

15. Rodbell, M. (1966). The metabolism of isolated fat cells. IV. Regulation of release of protein by lipolytic hormones and insulin. Journal of Biological Chemistry, 241, 3909-3917.

16. Rodbell, M. (1966). Metabolism of isolated fat cells. II. The similar effects of phospholipase $\mathrm{C}$ (Clostridium perfringens alpha toxin) and of insulin on glucose and amino acid metabolism. The Journal of Biological Chemistry, 241, 130-139.

17. Rodbell, M., \& Jones, A. B. (1966). Metabolism of isolated fat cells. 3. The similar inhibitory action of phospholipase C (Clostridium perfringens alpha toxin) and of insulin on lipolysis stimulated by lipolytic hormones and theophylline. The Journal of Biological Chemistry, 241, 140-142.

18. Arnalich-Montiel, F., Pastor, S., Blazquez-Martinez, A., Fernandez-Delgado, J., Nistal, M., Alio, J. L., \& De Miguel, M. P. (2008). Adipose-derived stem cells are a source for cell therapy of the corneal stroma. Stem Cells, 26, 570-579.

19. Rigotti, G., Charles-de-Sa, L., Gontijo-de-Amorim, N. F., Takiya, C. M., Amable, P. R., Borojevic, R., Benati, D., Bernardi, P., \& Sbarbati, A. (2016). Expanded stem cells, stromal-vascular fraction, and platelet-rich plasma enriched fat: Comparing results of different facial rejuvenation approaches in a clinical trial. Aesthetic Surgery Journal, 36, 261-270.

20. Hillmann, A., Ahrberg, A. B., Brehm, W., Heller, S., Josten, C., Paebst, F., \& Burk, J. (2016). Comparative characterization of human and equine Mesenchymal stromal cells: A basis for translational studies in the equine model. Cell Transplantation, 25, 109-124.

21. Lee, A. Y., Lee, J., Kim, C. L., Lee, K. S., Lee, S. H., Gu, N. Y., Kim, J. M., Lee, B. C., Koo, O. J., Song, J. Y., \& Cha, S. H.
(2015). Comparative studies on proliferation, molecular markers and differentiation potential of mesenchymal stem cells from various tissues (adipose, bone marrow, ear skin, abdominal skin, and lung) and maintenance of multipotency during serial passages in miniature pig. Research in Veterinary Science, 100, 115-124.

22. Shojaee, A., \& Parham, A. (2019). Strategies of tenogenic differentiation of equine stem cells for tendon repair: Current status and challenges. Stem Cell Research \& Therapy, 10, 181.

23. Hanson, S. E., Kleinbeck, K. R., Cantu, D., Kim, J., Bentz, M. L., Faucher, L. D., Kao, W. J., \& Hematti, P. (2016). Local delivery of allogeneic bone marrow and adipose tissue-derived mesenchymal stromal cells for cutaneous wound healing in a porcine model. Journal of Tissue Engineering and Regenerative Medicine, 10, E90-E100.

24. Choe, S. S., Huh, J. Y., Hwang, I. J., Kim, J. I., \& Kim, J. B. (2016). Adipose tissue remodeling: Its role in energy metabolism and metabolic disorders. Frontiers in Endocrinology (Lausanne), 7,30 .

25. Bourin, P., Bunnell, B. A., Casteilla, L., Dominici, M., Katz, A. J., March, K. L., Redl, H., Rubin, J. P., Yoshimura, K., \& Gimble, J. M. (2013). Stromal cells from the adipose tissue-derived stromal vascular fraction and culture expanded adipose tissue-derived stromal/stem cells: A joint statement of the International Federation for Adipose Therapeutics and Science (IFATS) and the International Society for Cellular Therapy (ISCT). Cytotherapy, 15, 641-648.

26. Zwick, R. K., Guerrero-Juarez, C. F., Horsley, V., \& Plikus, M. V. (2018). Anatomical, physiological, and functional diversity of adipose tissue. Cell Metabolism, 27, 68-83.

27. Hwang, I. S., Bae, H. K., \& Cheong, H. T. (2015). Comparison of the characteristics and multipotential and in vivo cartilage formation capabilities between porcine adipose-derived stem cells and porcine skin-derived stem cell-like cells. American Journal of Veterinary Research, 76, 814-821.

28. Perruchot, M. H., Lefaucheur, L., Barreau, C., Casteilla, L., \& Louveau, I. (2013). Age-related changes in the features of porcine adult stem cells isolated from adipose tissue and skeletal muscle. American Journal of Physiology. Cell Physiology, 305, C728-C738.

29. Schwarz, C., Leicht, U., Rothe, C., Drosse, I., Luibl, V., Rocken, M., \& Schieker, M. (2012). Effects of different media on proliferation and differentiation capacity of canine, equine and porcine adipose derived stem cells. Research in Veterinary Science, 93, 457-462.

30. Song, S. H., Kumar, B. M., Kang, E. J., Lee, Y. M., Kim, T. H., Ock, S. A., Lee, S. L., Jeon, B. G., \& Rho, G. J. (2011). Characterization of porcine multipotent stem/stromal cells derived from skin, adipose, and ovarian tissues and their differentiation in vitro into putative oocyte-like cells. Stem Cells and Development, 20, 1359-1370.

31. Arrigoni, E., Lopa, S., de Girolamo, L., Stanco, D., \& Brini, A. T. (2009). Isolation, characterization and osteogenic differentiation of adipose-derived stem cells: From small to large animal models. Cell and Tissue Research, 338, 401-411.

32. Bruckner, S., Tautenhahn, H. M., Winkler, S., Stock, P., Dollinger, M., \& Christ, B. (2014). A fat option for the pig: Hepatocytic differentiated mesenchymal stem cells for translational research. Experimental Cell Research, 321, 267-275.

33. Wang, K. H., Kao, A. P., Wangchen, H., Wang, F. Y., Chang, C. H., Chang, C. C., \& Lin, S. D. (2008). Optimizing proliferation and characterization of multipotent stem cells from porcine adipose tissue. Biotechnology and Applied Biochemistry, 51, 159-166.

34. Alicka, M., Kornicka-Garbowska, K., Kucharczyk, K., Kepska, M., Rcken, M., \& Marycz, K. (2020). Age-dependent impairment of adipose-derived stem cells isolated from horses. Stem Cell Research \& Therapy, 11, 4.

35. Maredziak, M., Marycz, K., Smieszek, A., Lewandowski, D., \& Toker, N. Y. (2014). The influence of static magnetic fields on 
canine and equine mesenchymal stem cells derived from adipose tissue. In Vitro Cellular \& Developmental Biology. Animal, 50, 562-571.

36. Raabe, O., Shell, K., Goessl, A., Crispens, C., Delhasse, Y., Eva, A., Scheiner-Bobis, G., Wenisch, S., \& Arnhold, S. (2013). Effect of extracorporeal shock wave on proliferation and differentiation of equine adipose tissue-derived mesenchymal stem cells in vitro. American Journal of Stem Cells, 2, 62-73.

37. Arnhold, S., Elashry, M. I., Klymiuk, M. C., \& Geburek, F. (2019). Investigation of stemness and multipotency of equine adipose-derived mesenchymal stem cells (ASCs) from different fat sources in comparison with lipoma. Stem Cell Research \& Therapy, 10, 309.

38. Burk, J., Ribitsch, I., Gittel, C., Juelke, H., Kasper, C., Staszyk, C., $\&$ Brehm, W. (2013). Growth and differentiation characteristics of equine mesenchymal stromal cells derived from different sources. Veterinary Journal, 195, 98-106.

39. Marycz, K., Weiss, C., Smieszek, A., \& Kornicka, K. (2018). Evaluation of oxidative stress and Mitophagy during Adipogenic differentiation of adipose-derived stem cells isolated from equine metabolic syndrome (EMS) horses. Stem Cells International, $2018,5340756$.

40. Ranera, B., Ordovas, L., Lyahyai, J., Bernal, M. L., Fernandes, F., Remacha, A. R., Romero, A., Vazquez, F. J., Osta, R., Cons, C., Varona, L., Zaragoza, P., Martin-Burriel, I., \& Rodellar, C. (2012). Comparative study of equine bone marrow and adipose tissue-derived mesenchymal stromal cells. Equine Veterinary Journal, 44, 33-42.

41. Marinas-Pardo, L., Garcia-Castro, J., Rodriguez-Hurtado, I., Rodriguez-Garcia, M. I., Nunez-Naveira, L., \& Hermida-Prieto, M. (2018). Allogeneic adipose-derived Mesenchymal stem cells (horse Allo 20) for the treatment of osteoarthritis-associated lameness in horses: Characterization, safety, and efficacy of intraarticular treatment. Stem Cells and Development, 27, 1147-1160.

42. Vahedi, P., Soleimanirad, J., Roshangar, L., Shafaei, H., Jarolmasjed, S., \& Nozad Charoudeh, H. (2016). Advantages of sheep Infrapatellar fat pad adipose tissue derived stem cells in tissue engineering. Advanced Pharmaceutical Bulletin, 6, 105110.

43. Zhao, Y., Waldman, S. D., \& Flynn, L. E. (2012). The effect of serial passaging on the proliferation and differentiation of bovine adipose-derived stem cells. Cells, Tissues, Organs, 195, 414-427.

44. Niada, S., Ferreira, L. M., Arrigoni, E., Addis, A., Campagnol, M., Broccaioli, E., \& Brini, A. T. (2013). Porcine adipose-derived stem cells from buccal fat pad and subcutaneous adipose tissue for future preclinical studies in oral surgery. Stem Cell Research \& Therapy, 4, 148.

45. Bonnet, M., Cassar-Malek, I., Chilliard, Y., \& Picard, B. (2010). Ontogenesis of muscle and adipose tissues and their interactions in ruminants and other species. Animal, 4, 1093-1109.

46. Moura, L. B., Spin, J. R., Spin-Neto, R., \& Pereira-Filho, V. A. (2018). Buccal fat pad removal to improve facial aesthetics: An established technique? Medicina Oral, Patología Oral y Cirugía Bucal, 23, e478-e484.

47. Bunnell, B. A., Flaat, M., Gagliardi, C., Patel, B., \& Ripoll, C. (2008). Adipose-derived stem cells: Isolation, expansion and differentiation. Methods, 45, 115-120.

48. Frazier, T. P., Gimble, J. M., Kheterpal, I., \& Rowan, B. G. (2013). Impact of low oxygen on the secretome of human adipose-derived stromal/stem cell primary cultures. Biochimie, 95, 2286-2296.

49. Ge, Y., Zhang, Q., Jiao, Z., Li, H., Bai, G., \& Wang, H. (2018). Adipose-derived stem cells reduce liver oxidative stress and autophagy induced by ischemia-reperfusion and hepatectomy injury in swine. Life Sciences, 214, 62-69.
50. Lu, T., Xiong, H., Wang, K., Wang, S., Ma, Y., \& Guan, W. (2014). Isolation and characterization of adipose-derived mesenchymal stem cells (ADSCs) from cattle. Applied Biochemistry and Biotechnology, 174, 719-728.

51. Grzesiak, J., Krzysztof, M., Karol, W., \& Joanna, C. (2011). Isolation and morphological characterisation of ovine adiposederived mesenchymal stem cells in culture. International Journal of Stem Cells, 4, 99-104.

52. Ihara, K., Fukuda, S., Enkhtaivan, B., Trujillo, R., Perez-Bello, D., Nelson, C., Randolph, A., Alharbi, S., Hanif, H., Herndon, D., Prough, D., \& Enkhbaatar, P. (2017). Adipose-derived stem cells attenuate pulmonary microvascular hyperpermeability after smoke inhalation. PLoS One, 12, e0185937.

53. Sampaio, R. V., Chiaratti, M. R., Santos, D. C., Bressan, F. F., Sangalli, J. R., Sa, A. L., Silva, T. V., Costa, N. N., Cordeiro, M. S., Santos, S. S., Ambrosio, C. E., Adona, P. R., Meirelles, F. V., Miranda, M. S., \& Ohashi, O. M. (2015). Generation of bovine (Bos indicus) and buffalo (Bubalus bubalis) adipose tissue derived stem cells: Isolation, characterization, and multipotentiality. Genetics and Molecular Research, 14, 53-62.

54. Castro, F. O., Torres, A., Cabezas, J., \& Rodriguez-Alvarez, L. L. (2014). Combined use of platelet rich plasma and vitamin C positively affects differentiation in vitro to mesodermal lineage of adult adipose equine mesenchymal stem cells. Research in Veterinary Science, 96, 95-101.

55. Marycz, K., Kornicka, K., Basinska, K., \& Czyrek, A. (2016). Equine metabolic syndrome affects viability, senescence, and stress factors of equine adipose-derived Mesenchymal stromal stem cells: New insight into EqASCs Isolated from EMS horses in the context of their aging. Oxidative Medicine and Cellular Longevity, 2016, 4710326.

56. Dariolli, R., Bassaneze, V., Nakamuta, J. S., Omae, S. V., Campos, L. C., \& Krieger, J. E. (2013). Porcine adipose tissuederived mesenchymal stem cells retain their proliferative characteristics, senescence, karyotype and plasticity after long-term cryopreservation. PLoS One, 8, e67939.

57. Castro-Malaspina, H., Gay, R. E., Resnick, G., Kapoor, N., Meyers, P., Chiarieri, D., McKenzie, S., Broxmeyer, H. E., \& Moore, M. A. (1980). Characterization of human bone marrow fibroblast colony-forming cells (CFU-F) and their progeny. Blood, 56, 289-301.

58. Tang, L., Yin, Y., Zhou, H., Song, G., Fan, A., Tang, B., Shi, W., $\&$ Li, Z. (2012). Proliferative capacity and pluripotent characteristics of porcine adult stem cells derived from adipose tissue and bone marrow. Cellular Reprogramming, 14, 342-352.

59. da Silva, M. L., Sand, T. T., Harman, R. J., Lennon, D. P., \& Caplan, A. I. (2009). MSC frequency correlates with blood vessel density in equine adipose tissue. Tissue Engineering. Part A, 15, 221-229.

60. Zannettino, A. C., Paton, S., Arthur, A., Khor, F., Itescu, S., Gimble, J. M., \& Gronthos, S. (2008). Multipotential human adipose-derived stromal stem cells exhibit a perivascular phenotype in vitro and in vivo. Journal of Cellular Physiology, 214, 413-421.

61. Ock, S. A., Lee, Y. M., Park, J. S., Shivakumar, S. B., Moon, S. W., Sung, N. J., Lee, W. J., Jang, S. J., Park, J. M., Lee, S. C., Lee, S. L., \& Rho, G. J. (2016). Evaluation of phenotypic, functional and molecular characteristics of porcine mesenchymal stromal/ stem cells depending on donor age, gender and tissue source. The Journal of Veterinary Medical Science, 78, 987-995.

62. Santos Rizzo Zuttion, M. S., Dias Camara, D. A., Dariolli, R., Takimura, C., Wenceslau, C., \& Kerkis, I. (2019). In vitro heterogeneity of porcine adipose tissue-derived stem cells. Tissue \& Cell, 58, 51-60.

63. Bobi, J., Solanes, N., Fernandez-Jimenez, R., Galan-Arriola, C., Dantas, A. P., Fernandez-Friera, L., Galvez-Monton, C., Rigol- 
Monzo, E., Aguero, J., Ramirez, J., Roque, M., Bayes-Genis, A., Sanchez-Gonzalez, J., Garcia-Alvarez, A., Sabate, M., Roura, S., Ibanez, B., \& Rigol, M. (2017). Intracoronary administration of allogeneic adipose tissue-derived mesenchymal stem cells improves myocardial perfusion but not left ventricle function, in a translational model of acute myocardial infarction. Journal of the American Heart Association, 6, e005771.

64. Ge, Y., Zhang, Q., Li, H., Bai, G., Jiao, Z., \& Wang, H. (2018). Adipose-derived stem cells alleviate liver apoptosis induced by ischemia-reperfusion and laparoscopic hepatectomy in swine. Scientific Reports, 8, 16878.

65. Liu, H. Y., Chen, C. C., Lin, Y. Y., Chen, Y. J., Liu, B. H., Wong, S. C., Wu, C. Y., Chang, Y. T., Chou, H. E., \& Ding, S. T. (2017). Chitosan-assisted differentiation of porcine adipose tissue-derived stem cells into glucose-responsive insulin-secreting clusters. PLoS One, 12, e0172922.

66. Xie, L., Zhang, N., Marsano, A., Vunjak-Novakovic, G., Zhang, Y., \& Lopez, M. J. (2013). In vitro mesenchymal trilineage differentiation and extracellular matrix production by adipose and bone marrow derived adult equine multipotent stromal cells on a collagen scaffold. Stem Cell Reviews and Reports, 9, 858-872.

67. Granero-Molto, F., Weis, J. A., Miga, M. I., Landis, B., Myers, T. J., O'Rear, L., Longobardi, L., Jansen, E. D., Mortlock, D. P., \& Spagnoli, A. (2009). Regenerative effects of transplanted mesenchymal stem cells in fracture healing. Stem Cells, 27, 1887-1898.

68. Lee, J. S., Hong, J. M., Moon, G. J., Lee, P. H., Ahn, Y. H., \& Bang, O. Y. (2010). A long-term follow-up study of intravenous autologous mesenchymal stem cell transplantation in patients with ischemic stroke. Stem Cells, 28, 1099-1106.

69. Davison, A. C. (2010). Brave pioneers or clinical cowboys? Cell Stem Cell, 6, 504-505.

70. Del Bue, M., Ricco, S., Ramoni, R., Conti, V., Gnudi, G., \& Grolli, S. (2008). Equine adipose-tissue derived mesenchymal stem cells and platelet concentrates: Their association in vitro and in vivo. Veterinary Research Communications, 32, S51-S55.

71. Deng, Y. F., Huang, G. T., Che, F., Testroet, E. D., Li, H., Li, H. Y., Nong, T. Y., Yang, X. L., Cui, J. Y., Shi, D. S., \& Yang, S. F. (2019). Hypoxia enhances buffalo adipose-derived mesenchymal stem cells proliferation, stemness, and reprogramming into induced pluripotent stem cells. Journal of Cellular Physiology, 234, 17254-17268.

72. Kisiday, J. D., Kopesky, P. W., Evans, C. H., Grodzinsky, A. J., McIlwraith, C. W., \& Frisbie, D. D. (2008). Evaluation of adult equine bone marrow- and adipose-derived progenitor cell chondrogenesis in hydrogel cultures. Journal of Orthopaedic Research, 26, 322-331.

73. Follin, B., Ghotbi, A. A., Clemmensen, A. E., Bentsen, S., Juhl, M., Sondergaard, R. H., Lund, L. D., Haack-Sorensen, M., Hasbak, P., Cohen, S., Ripa, R. S., Kastrup, J., Ekblond, A., \& Kjaer, A. (2018). Retention and functional effect of adiposederived stromal cells administered in alginate hydrogel in a rat model of acute myocardial infarction. Stem Cells International, 2018, 7821461

74. Zhang, Y., Wei, C., Zhang, P. F., Li, X., Liu, T., Pu, Y., Li, Y. S., Cao, Z. B., Cao, H. G., Liu, Y., Zhang, X. R., \& Zhang, Y. H. (2014). Efficient reprogramming of naive-like induced pluripotent stem cells from porcine adipose-derived stem cells with a feederindependent and serum-free system. PLoS One, 9, e85089.

75. Chen, L. W., Tredget, E. E., Wu, P. Y. G., \& Wu, Y. J. (2008). Paracrine factors of Mesenchymal stem cells recruit macrophages and endothelial lineage cells and enhance wound healing. PLoS One, 3.

76. Wu, Y. J., Chen, L., Scott, P. G., \& Tredget, E. E. (2007). Mesenchymal stem cells enhance wound healing through differentiation and angiogenesis. Stem Cells, 25, 2648-2659.
77. Fontanilla, C. V., Gu, H. Y., Liu, Q. P., Zhu, T. Z., Zhou, C. W., Johnstone, B. H., March, K. L., Pascuzzi, R. M., Farlow, M. R., \& Du, Y. S. (2016). Adipose-derived stem cell conditioned media extends survival time of a mouse model of amyotrophic lateral sclerosis. Scientific Reports, 5, 16953.

78. Zhou, B. R., Xu, Y., Guo, S. L., Xu, Y., Wang, Y., Zhu, F., Permatasari, F., Wu, D., Yin, Z. Q., \& Luo, D. (2013). The effect of conditioned media of adipose-derived stem cells on wound healing after ablative fractional carbon dioxide laser resurfacing. BioMed Research International, 2013, 519126.

79. Hocking, A. M., \& Gibran, N. S. (2010). Mesenchymal stem cells: Paracrine signaling and differentiation during cutaneous wound repair. Experimental Cell Research, 316, 2213-2219.

80. Salgado, A. J., Reis, R. L., Sousa, N., \& Gimble, J. M. (2010). Adipose tissue derived stem cells Secretome: Soluble factors and their roles in regenerative medicine. Current Stem Cell Research \& Therapy, 5, 103-110.

81. Pascucci, L., Alessandri, G., Dall'Aglio, C., Mercati, F., Coliolo, P., Bazzucchi, C., Dante, S., Petrini, S., Curina, G., \& Ceccarelli, P. (2014). Membrane vesicles mediate pro-angiogenic activity of equine adipose-derived mesenchymal stromal cells. Veterinary Journal, 202, 361-366.

82. Klymiuk, M. C., Balz, N., Elashry, M. I., Heimann, M., Wenisch, S., \& Arnhold, S. (2019). Exosomes isolation and identification from equine mesenchymal stem cells. BMC Veterinary Research, 15,42 .

83. Bowles, A. C., Wise, R. M., Gerstein, B. Y., Thomas, R. C., Ogelman, R., Febbo, I., \& Bunnell, B. A. (2017). Immunomodulatory effects of adipose stromal vascular fraction cells promote alternative activation macrophages to repair tissue damage. Stem Cells, 35, 2198-2207.

84. Melief, S. M., Zwaginga, J. J., Fibbe, W. E., \& Roelofs, H. (2013). Adipose tissue-derived multipotent stromal cells have a higher Immunomodulatory capacity than their bone marrow-derived counterparts. Stem Cells Translational Medicine, 2, 455-463.

85. Puissant, N., Barreau, C., Bourin, P., Clavel, C., Corre, J., Bousquet, C., Taureau, C., Cousin, B., Abbal, M., Laharrague, P., Penicaud, L., Casteilla, L., \& Blancher, A. (2005). Immunomodulatory effect of human adipose tissue-derived adult stem cells: Comparison with bone marrow mesenchymal stem cells. British Journal of Haematology, 129, 118-129.

86. Bunnell, B. A., Betancourt, A. M., \& Sullivan, D. E. (2010). New concepts on the immune modulation mediated by mesenchymal stem cells. Stem Cell Research \& Therapy, 1, 34.

87. Carrade, D. D., Lame, M. W., Kent, M. S., Clark, K. C., Walker, N. J., \& Borjesson, D. L. (2012). Comparative analysis of the Immunomodulatory properties of equine adult-derived Mesenchymal stem cells(). Cell Medicine, 4, 1-11.

88. Holt, D. D. C., Wood, J. A., Granick, J. L., Walker, N. J., Clark, K. C., \& Borjesson, D. L. (2014). Equine Mesenchymal stem cells inhibit $\mathrm{T}$ cell proliferation through different mechanisms depending on tissue source. Stem Cells and Development, 23, 12581265 .

89. Falomo, M. E., Ferroni, L., Tocco, I., Gardin, C., \& Zavan, B. (2015). Immunomodulatory role of adipose-derived stem cells on equine endometriosis. BioMed Research International, 2015, 141485.

90. Nielsen, E. O., Chen, L., Hansen, J. O., Degn, M., Overgaard, S., \& Ding, M. (2018). Optimizing osteogenic differentiation of ovine adipose-derived stem cells by osteogenic induction medium and FGFb, BMP2, or NELL1 in vitro. Stem Cells International, 2018, 9781393

91. Kalaszczynska, I., Ruminski, S., Platek, A. E., Bissenik, I., Zakrzewski, P., Noszczyk, M., \& Lewandowska-Szumiel, M. (2013). Substantial differences between human and ovine 
mesenchymal stem cells in response to osteogenic media: How to explain and how to manage? Biores Open Access, 2, 356-363.

92. Hu, L., Wang, J., Zhou, X., Xiong, Z. H., Zhao, J. J., Yu, R., Huang, F., Zhang, H. D., \& Chen, L. L. (2016). Exosomes derived from human adipose mensenchymal stem cells accelerates cutaneous wound healing via optimizing the characteristics of fibroblasts. Scientific Reports, 6, 32993.

93. Wang, L., Hu, L., Zhou, X., Xiong, Z. H., Zhang, C. G., Shehada, H. M. A., Hu, B., Song, J. L., \& Chen, L. L. (2017). Exosomes secreted by human adipose mesenchymal stem cells promote scarless cutaneous repair by regulating extracellular matrix remodelling. Scientific Reports, 7, 13321.

94. Lokmic, Z., Musyoka, J., Hewitson, T. D., \& Darby, I. A. (2012). Hypoxia and hypoxia signaling in tissue repair and fibrosis. International Review of Cell and Molecular Biology, 296, 139185

95. Hu, X. Y., Yu, S. P., Fraser, J. L., Lu, Z. Y., Ogle, M. E., Wang, J. A., \& Wei, L. (2008). Transplantation of hypoxia-preconditioned mesenchymal stem cells improves infarcted heart function via enhanced survival of implanted cells and angiogenesis. Journal of Thoracic and Cardiovascular Surgery, 135, 799-808.

96. Stubbs, S. L., Hsiao, S. T., Peshavariya, H. M., Lim, S. Y., Dusting, G. J., \& Dilley, R. J. (2012). Hypoxic preconditioning enhances survival of human adipose-derived stem cells and conditions endothelial cells in vitro. Stem Cells and Development, 21, 1887-1896.

97. Theus, M. H., Wei, L., Cui, L., Francis, K., Hu, X. Y., Keogh, C., $\&$ Yu, S. P. (2008). In vitro hypoxic preconditioning of embryonic stem cells as a strategy of promoting cell survival and functional benefits after transplantation into the ischemic rat brain. Experimental Neurology, 210, 656-670.

98. Shell, K., Raabe, O., Freitag, C., Ohrndorf, A., Christ, H. J., Wenisch, S., \& Arnhold, S. (2013). Comparison of equine adipose tissue-derived stem cell behavior and differentiation potential under the influence of $3 \%$ and $21 \%$ oxygen tension. Journal of Equine Veterinary Science, 33, 74-82.

99. Barre-Sinoussi, F., \& Montagutelli, X. (2015). Animal models are essential to biological research: Issues and perspectives. Future Science OA, 1, FSO63.

100. Irons, R. F., Cahill, K. W., Rattigan, D. A., Marcotte, J. H., Framer, M. W., Chang, S. H., Carpenter, J. P., \& Caputo, F. J. (2017). Acceleration of diabetic wound healing with adiposederived stem cells, endothelial-differentiated stem cells, and topical-conditioned medium therapy in a swine model. Journal of Vascular Surgery, 65, 184s-185s.

101. James, I., Bourne, D., Silva, M., Havis, E., Albright, K., Zhang, L., Kostereva, N., Wang, S., DiBernardo, G., Guest, R., Lei, J., Almadori, A., Satish, L., Marra, K., \& Rubin, J. P. (2018). Adipose stem cells enhance excisional wound healing in a porcine model. The Journal of Surgical Research, 229, 243-253.

102. Rapp, S. J., Pan, B. S., Schwentker, A. R., \& Van Aalst, J. (2017). Effects of autologous fat and ASCs on swine hypertrophic burn scars: A multimodal quantitative analysis. Plastic and Reconstructive Surgery. Global Open, 5, e1547.

103. Hadad, I., Johnstone, B. H., Brabham, J. G., Blanton, M. W., Rogers, P. I., Fellers, C., Solomon, J. L., Merfeld-Clauss, S., DesRosiers, C. M., Dynlacht, J. R., Coleman, J. J., \& March, K. L. (2010). Development of a porcine delayed wound-healing model and its use in testing a novel cell-based therapy. International Journal of Radiation Oncology Biology Physics, $78,888-896$.

104. Blanton, M. W., Hadad, I., Johnstone, B. H., Mund, J. A., Rogers, P. I., Eppley, B. L., \& March, K. L. (2009). Adipose stromal cells and platelet-rich plasma therapies synergistically increase revascularization during wound healing. Plastic and Reconstructive Surgery, 123, 56s-64s.
105. Alt, E., Pinkernell, K., Scharlau, M., Coleman, M., Fotuhi, P., Nabzdyk, C., Matthias, N., Gehmert, S., \& Song, Y. H. (2010). Effect of freshly isolated autologous tissue resident stromal cells on cardiac function and perfusion following acute myocardial infarction. International Journal of Cardiology, 144, 26-35.

106. Valina, C., Pinkernell, K., Song, Y. H., Bai, X., Sadat, S., Campeau, R. J., Le Jemtel, T. H., \& Alt, E. (2007). Intracoronary administration of autologous adipose tissuederived stem cells improves left ventricular function, perfusion, and remodelling after acute myocardial infarction. European Heart Journal, 28, 2667-2677.

107. Rigol, M., Solanes, N., Farre, J., Roura, S., Roque, M., Berruezo, A., Bellera, N., Novensa, L., Tamborero, D., Prat-Vidal, C., Huzman, M. A., Batlle, M., Hoefsloot, M., Sitges, M., Ramirez, J., Dantas, A. P., Merino, A., Sanz, G., Brugada, J., Bayes-Genis, A., \& Heras, M. (2010). Effects of adipose tissue-derived stem cell therapy after myocardial infarction: Impact of the route of administration. Journal of Cardiac Failure, 16, 357-366.

108. Mazo, M., Hernandez, S., Gavira, J. J., Abizanda, G., Arana, M., Lopez-Martinez, T., Moreno, C., Merino, J., Martino-Rodriguez, A., Uixeira, A., Garcia de Jalon, J. A., Pastrana, J., Martinez-Caro, D., \& Prosper, F. (2012). Treatment of reperfused ischemia with adipose-derived stem cells in a preclinical swine model of myocardial infarction. Cell Transplantation, 21, 2723-2733.

109. Ricco, S., Renzi, S., Del Bue, M., Conti, V., Merli, E., Ramoni, R., Lucarelli, E., Gnudi, G., Ferrari, M., \& Grolli, S. (2013). Allogeneic adipose tissue-derived mesenchymal stem cells in combination with platelet rich plasma are safe and effective in the therapy of superficial digital flexor tendonitis in the horse. International Journal of Immunopathology and Pharmacology, 26, 61-68.

110. Guercio, A., Di Marco, P., Casella, S., Russotto, L., Puglisi, F., Majolino, C., Giudice, E., Di Bella, S., Purpari, G., Cannella, V., \& Piccione, G. (2015). Mesenchymal stem cells derived from subcutaneous fat and platelet-rich plasma used in athletic horses with lameness of the superficial digital flexor tendon. Journal of Equine Veterinary Science, 35, 19-26.

111. Mambelli, L. I., Winter, G. H., Kerkis, A., Malschitzky, E., Mattos, R. C., \& Kerkis, I. (2013). A novel strategy of mesenchymal stem cells delivery in the uterus of mares with endometrosis. Theriogenology, 79, 744-750.

112. Mambelli, L. I., Mattos, R. C., Winter, G. H., Madeiro, D. S., Morais, B. P., Malschitzky, E., Miglino, M. A., Kerkis, A., \& Kerkis, I. (2014). Changes in expression pattern of selected endometrial proteins following mesenchymal stem cells infusion in mares with endometrosis. PLoS One, 9, e97889.

113. Meyer, W., Neurand, K., \& Schwarz, R. (1978). Significance of apocrine skin glands of general body-surface of different domestic mammals. Deutsche Tierärztliche Wochenschrift, 85, 194-197.

114. Wollina, U., Berger, U., \& Mahrle, G. (1991). Immunohistochemistry of porcine skin. Acta Histochemica, 90, 87-91.

115. Seaton, M., Hocking, A., \& Gibran, N. S. (2015). Porcine models of cutaneous wound healing. ILAR Journal, 56, 127-138.

116. Sullivan, T. P., Eaglstein, W. H., Davis, S. C., \& Mertz, P. (2001). The pig as a model for human wound healing. Wound Repair and Regeneration, 9, 66-76.

117. Crisostomo, V., Sun, F., Maynar, M., Baez-Diaz, C., Blanco, V., Garcia-Lindo, M., Uson-Gargallo, J., \& Sanchez-Margallo, F. M. (2016). Common swine models of cardiovascular disease for research and training. Lab Animal, 45, 67-74.

118. Goodrich, L. R., \& Nixon, A. J. (2006). Medical treatment of osteoarthritis in the horse - a review. Veterinary Journal, 171, 51-69.

119. McIlwraith, C. W., Fortier, L. A., Frisbie, D. D., \& Nixon, A. J. (2011). Equine models of articular cartilage repair. Cartilage, 2, 317-326. 
120. Mcllwraith, C. W., Frisbie, D. D., \& Kawcak, C. E. (2012). The horse as a model of naturally occurring osteoarthritis. Bone and Joint Research, 1, 297-309.

121. Thorpe, C. T., Clegg, P. D., \& Birch, H. L. (2010). A review of tendon injury: Why is the equine superficial digital flexor tendon most at risk? Equine Veterinary Journal, 42, 174-180.

122. Hill, A. B. T., Bressan, F. F., Murphy, B. D., \& Garcia, J. M. (2019). Applications of mesenchymal stem cell technology in bovine species. Stem Cell Research \& Therapy, 10, 44.

123. Polejaeva, I. A., Rutigliano, H. M., \& Wells, K. D. (2016). Livestock in biomedical research: History, current status and future prospective. Reproduction, Fertility, and Development, 28, $112-124$.

124. Marx, C., Silveira, M. D., \& Nardi, N. B. (2015). Adipose-derived stem cells in veterinary medicine: Characterization and therapeutic applications. Stem Cells and Development, 24, 803-813.

125. Volk, S. W., \& Theoret, C. (2013). Translating stem cell therapies: The role of companion animals in regenerative medicine. Wound Repair and Regeneration, 21, 382-394.

126. Heo, S. C., Jeon, E. S., Lee, I. H., Kim, H. S., Kim, M. B., \& Kim, J. H. (2011). Tumor necrosis factor-alpha-activated human adipose tissue-derived Mesenchymal stem cells accelerate cutaneous wound healing through paracrine mechanisms. Journal of Investigative Dermatology, 131, 1559-1567.

127. Poirier, P., Giles, T. D., Bray, G. A., Hong, Y. L., Stern, J. S., PiSunyer, F. X., \& Eckel, R. H. (2006). Obesity and cardiovascular disease - pathophysiology, evaluation, and effect of weight loss. Arteriosclerosis, Thrombosis, and Vascular Biology, 26, 968976.

128. Warren, T. Y., Barry, V., Hooker, S. P., Sui, X. M., Church, T. S., $\&$ Blair, S. N. (2010). Sedentary behaviors increase risk of cardiovascular disease mortality in men. Medicine and Science in Sports and Exercise, 42, 879-885.

129. McLaughlin, S., McNeill, B., Podrebarac, J., Hosoyama, K., Sedlakova, V., Cron, G., Smyth, D., Seymour, R., Goel, K., Liang, W. B., Rayner, K. J., Ruel, M., Suuronen, E. J., \& Alarcon, E. I. (2019). Injectable human recombinant collagen matrices limit adverse remodeling and improve cardiac function after myocardial infarction. Nature Communications, 10, 4866.

130. Ma, T., Sun, J. C., Zhao, Z. A., Lei, W., Chen, Y. Q., Wang, X., Yang, J. J., \& Shen, Z. Y. (2017). A brief review: adipose-derived stem cells and their therapeutic potential in cardiovascular diseases. Stem Cell Research \& Therapy, 8, 124.

131. Fotuhi, P., Song, Y. H., \& Alt, E. (2007). Electrophysiological consequence of adipose-derived stem cell transplantation in infarcted porcine myocardium. Europace, 9, 1218-1221.

132. Rigol, M., Solanes, N., Roura, S., Roque, M., Novensa, L., Dantas, A. P., Martorell, J., Sitges, M., Ramirez, J., BayesGenis, A., \& Heras, M. (2014). Allogeneic adipose stem cell therapy in acute myocardial infarction. European Journal of Clinical Investigation, 44, 83-92.

133. Kuo, Y. R., Wang, C. T., Cheng, J. T., Kao, G. S., Chiang, Y. C., \& Wang, C. J. (2016). Adipose-derived stem cells accelerate diabetic wound healing through the induction of Autocrine and paracrine effects. Cell Transplantation, 25, 71-81.

134. Mitchell, R., Mellows, B., Sheard, J., Antonioli, M., Kretz, O., Chambers, D., Zeuner, M. T., Tomkins, J. E., Denecke, B., Musante, L., Joch, B., Debacq-Chainiaux, F., Holthofer, H., Ray, S., Huber, T. B., Dengjel, J., De Coppi, P., Widera, D., \& Patel, K. (2019). Secretome of adipose-derived mesenchymal stem cells promotes skeletal muscle regeneration through synergistic action of extracellular vesicle cargo and soluble proteins. Stem Cell Research \& Therapy, 10, 116.

135. Arnhold, S., \& Wenisch, S. (2015). Adipose tissue derived mesenchymal stem cells for musculoskeletal repair in veterinary medicine. American Journal of Stem Cells, 4, 1-12.
136. Dyson, S. J. (2004). Medical management of superficial digital flexor tendonitis: A comparative study in 219 horses (19922000). Equine Veterinary Journal, 36, 415-419.

137. O'Meara, B., Bladon, B., Parkin, T. D. H., Fraser, B., \& Lischer, C. J. (2010). An investigation of relationship between race performance and superficial digital flexor tendonitis in the thoroughbred racehorse (vol 42, pg 322, 2010). Equine Veterinary Journal, 42, 474-474.

138. Dowling, B. A., Dart, A. J., Hodgson, D. R., \& Smith, R. K. W. (2000). Superficial digital flexor tendonitis in the horse. Equine Veterinary Journal, 32, 369-378.

139. Richardson, L. E., Dudhia, J., Clegg, P. D., \& Smith, R. (2007). Stem cells in veterinary medicine - attempts at regenerating equine tendon after injury. Trends in Biotechnology, 25, 409-416.

140. Godwin, E. E., Young, N. J., Dudhia, J., Beamish, I. C., \& Smith, R. K. (2012). Implantation of bone marrow-derived mesenchymal stem cells demonstrates improved outcome in horses with overstrain injury of the superficial digital flexor tendon. Equine Veterinary Journal, 44, 25-32.

141. Van Loon, V. J., Scheffer, C. J., Genn, H. J., Hoogendoorn, A. C., \& Greve, J. W. (2014). Clinical follow-up of horses treated with allogeneic equine mesenchymal stem cells derived from umbilical cord blood for different tendon and ligament disorders. The Veterinary Quarterly, 34, 92-97.

142. Ortved, K. F. (2018). Regenerative medicine and rehabilitation for Tendinous and ligamentous injuries in sport horses. The Veterinary Clinics of North America. Equine Practice, 34, 359373.

143. Carvalho, A. D., Alves, A. L. G., de Oliveira, P. G. G., Alvarez, L. E. C., Amorim, R. L., Hussni, C. A., \& Deffune, E. (2011). Use of adipose tissue-derived Mesenchymal stem cells for experimental tendinitis therapy in equines. Journal of Equine Veterinary Science, 31, 26-34.

144. Carvalho, A. D., Badial, P. R., Alvarez, L. E. C., Yamada, A. L. M., Borges, A. S., Deffune, E., Hussni, C. A., \& Alves, A. L. G. (2013). Equine tendonitis therapy using mesenchymal stem cells and platelet concentrates: a randomized controlled trial. Stem Cell Research \& Therapy, 4, 85.

145. De Schauwer, C., Van de Walle, G. R., Van Soom, A., \& Meyer, E. (2013). Mesenchymal stem cell therapy in horses: Useful beyond orthopedic injuries? The Veterinary Quarterly, 33, 234-241.

146. Hoffmann, C., Ellenberger, C., Mattos, R. C., Aupperle, H., Dhein, S., Stief, B., \& Schoon, H. A. (2009). The equine endometrosis: New insights into the pathogenesis. Animal Reproduction Science, 111, 261-278.

147. Kenney, R. M. (1978). Cyclic and pathologic changes of the mare endometrium as detected by biopsy, with a note on early embryonic death. Journal of the American Veterinary Medical Association, 172, 241-262.

148. Lehmann, J., Ellenberger, C., Hoffmann, C., Bazer, F. W., Klug, J., Allen, W. R., Sieme, H., \& Schoon, H. A. (2011). Morphofunctional studies regarding the fertility prognosis of mares suffering from equine endometrosis. Theriogenology, 76, 1326-1336.

149. Szostek, A. Z., Siemieniuch, M. J., Lukasik, K., Galvao, A. M., Ferreira-Dias, G. M., \& Skarzynski, D. J. (2012). mRNA transcription of prostaglandin synthases and their products in the equine endometrium in the course of fibrosis. Theriogenology, 78, 768-776.

150. Szostek-Mioduchowska, A., Slowinska, M., Pacewicz, J., Skarzynski, D. J., \& Okuda, K. (2020). Matrix metallopeptidase expression and modulation by transforming growth factor-betal in equine endometrosis. Scientific Reports, 10, 1119.

Publisher's Note Springer Nature remains neutral with regard to jurisdictional claims in published maps and institutional affiliations. 